Research Article

\title{
Experimental and Numerical Investigation of Stepped Planing Hulls in Finding an Optimized Step Location and Analysis of Its Porpoising Phenomenon
}

\author{
Sayyed Mahdi Sajedi and Parviz Ghadimi \\ Department of Maritime Engineering, Amirkabir University of Technology, Tehran, Iran \\ Correspondence should be addressed to Parviz Ghadimi; pghadimi@aut.ac.ir
}

Received 2 June 2020; Revised 12 July 2020; Accepted 28 July 2020; Published 30 August 2020

Academic Editor: Andras Szekrenyes

Copyright (c) 2020 Sayyed Mahdi Sajedi and Parviz Ghadimi. This is an open access article distributed under the Creative Commons Attribution License, which permits unrestricted use, distribution, and reproduction in any medium, provided the original work is properly cited.

\begin{abstract}
Stability of a high-speed craft is an essential matter, and porpoising is one of the most critical instabilities that could occur in some planing hulls due to inappropriate design. In this paper, the porpoising phenomenon and variation of step location yielding resistance reduction are studied through experimental and numerical methods. The investigated models include a single-step model and a nonstep model with the same general shape, but with different step location. The nonstep model is previously tested, but the single-step model is examined in the present study. The nonstep model experiences porpoising at $8 \mathrm{~m} / \mathrm{s}$ speed, but the single-step model remains stable at the same speed. A three-dimensional CFD analysis is conducted using the finite volume method (FVM). On the contrary, the volume of fluid (VOF) scheme is used for free surface modeling, and the overset mesh technique is implemented within StarCCM+ software. The CFD results of total hydrodynamic resistance and dynamic trim angle are compared against the experimental data. The numerical results are in good agreement with the experimental data. Subsequently, ten different stepped models are simulated to examine their effects. The longitudinal distance between steps and aft of these models are in the range of 19 to 50 percent of the length of models. The obtained results show that as steps are located farther than aft, the models become more stable, and resistance increases due to trim reduction. Finally, the optimum location of the step is extracted with the aim of minimizing the resistance through the design of experiment (DOE) method. Based on the DOE method, it is observed that the sensitivity of the drag value to the step location is higher than the speed.
\end{abstract}

\section{Introduction}

Most of the weight in planing hulls is compensated by hydrodynamic lift [1]. On the other hand, through an increase in the speed, the drag to lift ratio increases. Providing transverse step(s) beneath the high-speed craft is one of the most important and practical strategies to reduce the drag to lift ratio. Transverse steps cause flow separation from the bottom of the vessel and lead to a reduction in the wetted surface area, which is the most effective factor in lowering the drag to lift ratio. Furthermore, transverse step(s) can make the pressure distribution more uniform and consequently improves the longitudinal stability of the vessel [2]. Hydrodynamic performance of a high-speed stepped craft is mostly dependent on the wetted surface area of the bottom.
Therefore, the wetted surface area can be a function of the height and location of the step, and finding the effects of height and locations of the step is the key to understanding the performance of the stepped hulls. In other words, reducing the drag-to-lift ratio and stabilizing the vessel necessitate the selection of the optimum height and location of the transverse step.

Different research studies have been conducted on the performance and behavior of planing hulls. Blount and Clement [3] studied the drag and streamlines around the hull of a high-speed craft. Savitsky [4] performed some model tests on prismatic vessels and provided some semiempirical formulae to estimate the resistance of planing hulls. Ghadimi et al. [5] used a mathematical model to study the response of planing crafts to environmental disturbances 
in the planing regime. One of the greatest theories proposed for examining the performance of a high-speed craft is $2 D+T$. In 2013, Haase et al. [6] investigated the behavior of a prismatic planing hull motion in head waves by $2 D+T$ theory. Ghadimi et al. [7] studied the running attitude of the warped planing hulls using a simple model based on the $2 D+T$ theory. Morabito [8] used slender body theory and estimated side forces acting on planing hulls and compared the results with the experimental data. Ghadimi et al. [9] also analyzed the roll motion in time domain and estimated its amplitude at different frequencies, based on $2 D+T$ theory. Recently, Kahramanoglu et al. [10] computed the damping coefficients of the roll motion for a high-speed craft using Unsteady Reynolds-Averaged Navier-Stokes (URANS) equations.

Deforming planing hulls and installing appendages have usually been interesting topics for naval architects. Karimi et al. [11] conducted an experimental study on planing mono-hull and catamaran models to examine the effects of an interceptor on the performance of these vessels. Sajedi et al. [12] investigated the effect of a wedge mounted on the rooster tail behind the vessel and analyzed the possibility of longitudinal instability, experimentally and numerically.

In the context of stepped planing hulls, Brizzolara and Serra [13] computed the resistance of a high-speed stepped craft. Their obtained results were in good agreement with the measurements by Shuford [14]. Savitsky et al. [15] studied the water spray caused by the motion of a high-speed craft in calm water and compared the spray resistance with other resistance components. Savitsky and Morabito [2], in 2010, conducted a series of experiments in Davidson Laboratory to capture the wake behind a high-speed craft. They used a prismatic model with constant deadrise angles of 10,20, and 30 degrees at various speeds. They aimed to formulate the wake behavior at different distances from stern of the vessels and provided some valuable relations. Seo et al. [16] considered the spray rail and experimentally examined the total drag and seakeeping of a high-speed craft. Jiang et al. [17] determined the performance of planing trimarans at various Froud numbers using experimental and numerical methods. De Marco et al. [18] studied the effect of step on hydrodynamic performance and flow pattern. The influence of the bubble injection process on the reduction of stepped hull resistance was investigated by Cucinotta et al. [19]. Other research studies conducted on the geometrical features of stepped planing hulls are summarized in Table 1.

In recent years, numerical study of stepped planing hulls has intensified. Doustdar and Kazemi [28] numerically investigated three body forms without a step, single-step, and two-step planing crafts and compared two different meshing methods to determine the limitations of the applied strategies. Najafi and Nowruzi [29] analyzed the effects of five different types of transverse steps on the lift to drag ratio, resistance, trim angle, and sinkage of high-speed planing crafts. Di Caterino et al. [30] optimized the unwetted aft body area behind the steps and defined its impact on the drag reduction and the dynamic stability of a multistepped hull. Ghadimi and Panahi [31] investigated three different planing hulls in a steady yawed condition to obtain the effects of steps on the hydrodynamic forces and moments acting on the hull. Very recently, Afriantoni et al. [32] numerically investigated the effects of step angle on the stability of stepped hulls using a speed control boat called Napoleon Patrol Boat. A summary of the numerical studies on the stepped hulls since 2019 is presented in Table 2.

Based on the conducted literature review, a comprehensive study on the effect of step location on the longitudinal instability (porpoising) of modern high-speed vessels at high Froude numbers has not been previously conducted. Therefore, in the present paper, the porpoising phenomenon is firstly studied in the case of nonstep and stepped planing hulls at above $8 \mathrm{~m} / \mathrm{s}$ speeds. Subsequently, the effect of step location is numerically investigated. Trim, resistance, and rise-up are assessed experimentally and numerically, and the results are evaluated. These results can play significant role in optimizing step designs. Ultimately, the optimum location of the step is extracted with the aim of minimizing the resistance using the design of experiment (DOE) method.

\section{Problem Definition}

The length of wetted keel and wetted chine in a high-speed craft usually vary according to unsteady flow behind the vessel. In this situation, improvement of the vessel's performance is a laborious task. In planing boats, the trim angle first increases and subsequently decreases. Choosing the proper trim angle provides a significant reduction in resistance. In addition to trim, rise-up of the vessel at the center of gravity varies; it initially decreases and subsequently increases. This increase in the rise-up is caused by an increase in the lift. These variations lead to an increase in the length of the wetted keel and wetted chine. Therefore, by deforming the bottom of planing hull, its trim, and rise-up change, these changes directly affect the resistance and stability of the vessel. Creating a step behind a planing hull is one of the most known strategies for reducing the resistance. However, an inappropriate step can possibly cause a transverse instability in the vessel. General behavior of stepped and nonstep vessels is shown in Figure 1.

Overall, there are four primary parameters in step design, which determine the performance of a stepped hull. These four parameters include hull geometry, kinematics of vessel, step geometry, and hydrostatics, respectively. The most influential parameters on the performance of the stepped hulls are categorized in Table 3.

One of the primary reasons for using transverse steps is its contribution to porpoising reduction. Porpoising is a longitudinal instability that occurs due to inappropriate distance between the center of gravity and dynamic pressure center. This phenomenon also depends on the moment of inertia and radius of gyration. Day and Haag [39] conducted systematic research on the Planning vessel. They created a diagram that could be used to identify an unstable area based on the deadrise angle. Subsequently, Celano [40] investigated the effect of boat scaling on the occurrence of the porpoising phenomenon on Day and Haag models [39]. He obtained a relation for 
TABLE 1: Previous studies conducted on the effect of geometrical parameters on hydrodynamic performance of a high-speed stepped craft.

\begin{tabular}{|c|c|c|c|c|c|c|}
\hline \multirow{2}{*}{ Researchers } & \multirow{2}{*}{ Study method } & \multirow{2}{*}{ Flow condition } & \multicolumn{4}{|c|}{ Investigated parameters } \\
\hline & & & Deadrise & Step profile & Step height & Step location \\
\hline Clement and Pope [20] & Empirical & Calm water & & & & \\
\hline Clement and Koelbel [21] & Empirical & Calm water & & & & \\
\hline Svahn [22] & Analytical & Calm water & & & & \\
\hline Makasyeyev [23] & Analytical & Calm water & & & & \\
\hline Taunton et al. [24] & Empirical & Calm water & & & & \\
\hline Taunton et al. [25] & Empirical & Calm water & & & & \\
\hline Lee et al. [26] & Empirical & Calm water & & & & \\
\hline Timmins [27] & Empirical & Calm water & & & & \\
\hline
\end{tabular}

TABLE 2: Numerical studies conducted on stepped planing hulls since 2019.

\begin{tabular}{|c|c|c|c|c|}
\hline No & Authors & General description & $\begin{array}{l}\text { Main investigated } \\
\text { topic }\end{array}$ & Year \\
\hline 1 & $\begin{array}{l}\text { Dongmei } \\
\text { et al. [33] }\end{array}$ & $\begin{array}{l}\text { They simulated flow field around the stepped planing hulls based on the FVM } \\
\text { (finite volume method) using the Taunton series. }\end{array}$ & Air cavity & 2019 \\
\hline 2 & Zou et al. [34] & $\begin{array}{l}\text { They examined the stern flap and double step as two general potential factors } \\
\text { in resistance reduction. }\end{array}$ & Flap and double step & 2019 \\
\hline 3 & $\begin{array}{l}\text { Ghadimi } \\
\text { et al. [35] }\end{array}$ & $\begin{array}{l}\text { This paper investigated the performance and hydrodynamic characteristics of a } \\
\text { double-stepped planing hull and the effects of adding two steps to the bottom of a monohull. }\end{array}$ & Double step & 2019 \\
\hline 4 & $\begin{array}{l}\text { Kazemi } \\
\text { et al. [36] }\end{array}$ & $\begin{array}{l}\text { They studied the effects of weight loading by simulating nonstep and single-step } \\
\text { planing hulls with free heave and pitch motions under different weight loadings. }\end{array}$ & Weight loading & 2019 \\
\hline 5 & $\begin{array}{l}\text { Chooran } \\
\text { et al. [37] }\end{array}$ & $\begin{array}{l}\text { This work addressed the numerical study of step height effect on hydrodynamic } \\
\text { performance of the planing hull. }\end{array}$ & Height step & 2019 \\
\hline 6 & Najafi et al. [38] & $\begin{array}{l}\text { In this paper, hydrodynamic resistance of a single-step planing craft was experimentally } \\
\text { investigated under different geometrical and physical conditions. To accomplish } \\
\text { this task, a Fridsma body model with varying angles of deadrise was considered. }\end{array}$ & Deadrise & 2019 \\
\hline
\end{tabular}

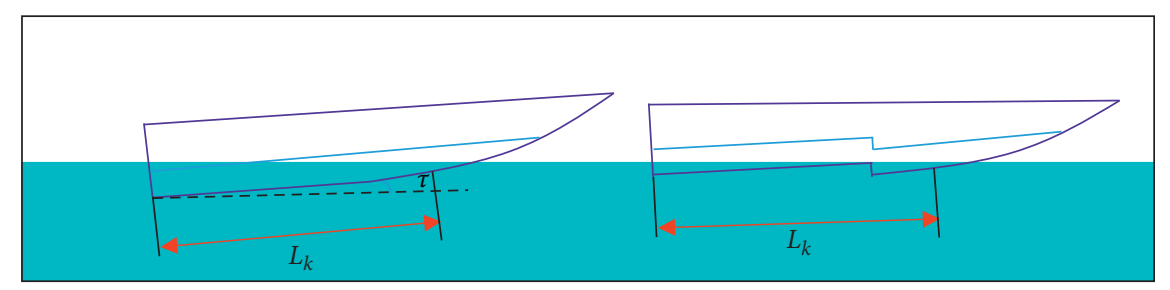

Figure 1: Schematic view of the wetted keel in nonstep and single-step models.

critical trim with the help of experimental works. This relation is as follows:

$$
t_{\text {Critical }}=0.1197 \beta_{\mathrm{deg}}^{0.7561} e^{15.7132 \sqrt{\left(C_{L} / 2\right)} \beta_{\mathrm{deg}}^{-0.2629}}
$$

where

$$
\sqrt{\frac{C_{L}}{2}}=\sqrt{\frac{C_{\Delta}}{C_{v}}} .
$$

Blount and Codego [41] identified the stability conditions based on equations (3) and (4)

$$
\begin{array}{r}
\frac{A_{p}}{\nabla^{(2 / 3)}} \leq 5.8, \\
\frac{\mathrm{CA}_{p}-\mathrm{LCG}}{L_{p}} \leq 0.03 .
\end{array}
$$

The effects of transverse steps on the resistance reduction and stability of the vessel are studied in the present paper.

\section{Experimental Tests}

Experiments are conducted on a nonstep and a single-step model with the same shape in the National Persian Gulf Towing Tank, and results are used to validate the numerical results. The nonstep model is previously tested by Ghadimi et al. [42], while the single-step model is examined in the present study. The length and beam of the model are $2.64 \mathrm{~m}$ and $0.551 \mathrm{~m}$, respectively, and the model has a constant deadrise angle of $24^{\circ}$. Weight of these models is $86 \mathrm{~kg}$, and their center of gravity is located at $0.791 \mathrm{~m}$ from the transom of the models. Principal characteristics of the nonstep model are shown in Table 4.

Height of the step in the model is $5 \mathrm{~cm}$, which is equal to 4 percent of the beam of this model. Step is located $0.670 \mathrm{~m}$ from the transom, which is equal to 25 percent of the length 
TABle 3: Categorization of the parameters affecting the hydrodynamics of a stepped hull.

\begin{tabular}{|c|c|c|}
\hline $\begin{array}{l}\text { The general types of parameters affecting the performance of a } \\
\text { stepped hull }\end{array}$ & $\begin{array}{l}\text { The parameters affecting the performance of a } \\
\text { stepped hull }\end{array}$ & $\begin{array}{c}\text { Scientific } \\
\text { symbol }\end{array}$ \\
\hline Hull geometry parameters & $\begin{array}{l}\text { (i) Overall length of vessel } \\
\text { (ii) Maximum beam of vessel } \\
\text { (iii) Deadrise angle }\end{array}$ & $\begin{array}{c}\text { LOA } \\
B \\
\beta\end{array}$ \\
\hline Kinematic parameters & $\begin{array}{l}\text { (i) Speed of vessel } \\
\text { (ii) Pressure distribution of bottom of vessel }\end{array}$ & $\begin{array}{l}V_{s} \\
p\end{array}$ \\
\hline Step geometry parameters & $\begin{array}{l}\text { (i) Ventilation in the aft of step } \\
\text { (ii) Number of steps } \\
\text { (iii) The distance from the step to the } \\
\text { transom stern } \\
\text { (iv) Height of steps }\end{array}$ & $\begin{array}{l}\text { - } \\
N \text {-Step } \\
\text { Ls } \\
\text { Hs }\end{array}$ \\
\hline Hydrostatic parameters & $\begin{array}{l}\text { (i) Center of gravity } \\
\text { (ii) Loading distribution of the vessel }\end{array}$ & $\begin{array}{l}\text { LCG-VCG } \\
\quad \Delta\end{array}$ \\
\hline
\end{tabular}

Table 4: Principal characteristic of the nonstep model.

\begin{tabular}{lcc}
\hline Parameter & Value & Unit \\
\hline$L$ & 2640 & mm \\
LCG & 791 & mm to transom \\
VCG & 184.6 & $\mathrm{~mm}$ \\
LBP & 2368.18 & $\mathrm{~mm}$ \\
$C_{\Delta}$ & 0.5096 & - \\
$m$ & 86.024 & $\mathrm{~kg}$ \\
$V$ & 0.08585 & $\mathrm{~m}^{3}$ \\
$\tau_{s}$ & 2.34 & degrees \\
$B$ & 551.9 & $\mathrm{~mm}$ \\
\hline
\end{tabular}

of this model. These models are constructed based on Cougar vessel with a length of $13 \mathrm{~m}$, a beam of $4 \mathrm{~m}$, and a weight of 11,000 kilograms. The body profile of these models is illustrated in Figure 2. All tests are conducted based on ITTC recommendation [43]. The length, beam, and depth of the towing tank are $400 \mathrm{~m}, 6 \mathrm{~m}$, and $4.5 \mathrm{~m}$, respectively. The carriage of this towing tank can reach up to $19 \mathrm{~m} / \mathrm{s}$ speed. The sway and yaw motions of the models are constrained, but pitch and heave motions are free during the tests. Figure 3 shows different views of the towing tank and locations of the sensors installed on the carrier, which include two potentiometers and one dynamometer. The dynamometer is mounted in the direction of the center of gravity to eliminate the longitudinal moment. As observed in Figure 3, there are four cameras located in front, behind, and sides of the models to capture the motions.

Results of the nonstep model, which are extracted by Ghadimi et al. [42], along with experimental measurements obtained in the present study are presented in Tables 5 and 6 at 1 to $8 \mathrm{~m} / \mathrm{s}$ speeds. The diagrams of resistance, trim, and rise-up are also given versus Froude number in Figure 4 for better comparison. The resistance and rise-up are dimensionless with respect to the ratio of resistance to weight $\left(R_{T} /\right.$ $\Delta)$ and rise-up to the third root of the underwater volume $(Z /$ $V^{0.3}$ ), respectively. As shown in Table 6, the single-step models exhibit the lowest resistance. The resistance drop of single-step models in the planing regime is due to the reduction in the wetted surface area behind the step. The nonstep model experiences porpoising at $8 \mathrm{~m} / \mathrm{s}$ speed, and measurement of the parameters in this condition is not possible. The symbol ' $p$ ' in Table 4 represents porpoising. However, the single-step model is stable at the same speed.

Figure 4(b) shows the highest trim reduction for the single-step model. Reduction in bow trim in stepped models is caused by an increase in the lift at the stern of these models. By an increase in the lift at the stern, the center of hydrodynamic pressure approaches the center of gravity, which delays the occurrence of porpoising. The diagram of the rise-up of the center of gravity of both models is presented in Figure 4(b). It is observed that nonstep and singlestep models experience the highest and lowest rise-up in the planing regime, respectively.

The two models are qualitatively compared at two speeds of 6 and $7 \mathrm{~m} / \mathrm{s}$ in Figure 5. Due to the occurrence of porpoising at $8 \mathrm{~m} / \mathrm{s}$ speed, no comparison is made for this case.

The uncertainties of the conducted tests are calculated following the recommendations of ITTC [44]. Uncertainties include five different sections of model geometry, model alignment, calibration, direct measurement, and equations. According to ITTC recommendations, uncertainties should be as low as possible. However, the allowable error rate of the measuring devices and physical characteristics of the towing tank are given in Table 7, according to ITTC.

Calculation of uncertainties associated with direct measurement includes trim, rise-up, and drag. These measurements are expressed as the percentages of trim angle, rise-up, center of gravity, and total drag coefficient. Computation of the uncertainties at $8 \mathrm{~m} / \mathrm{s}$ speed for all three 


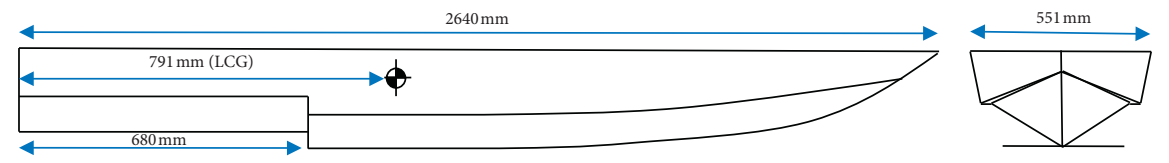

FIGURE 2: Body profile of the single-step models.

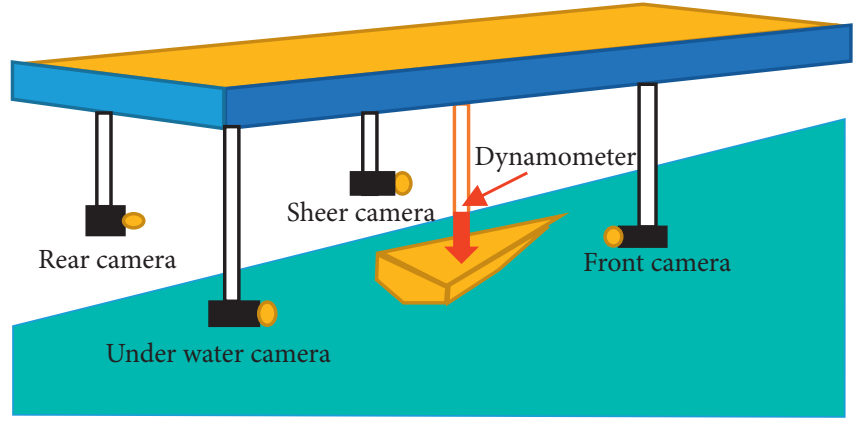

(a)

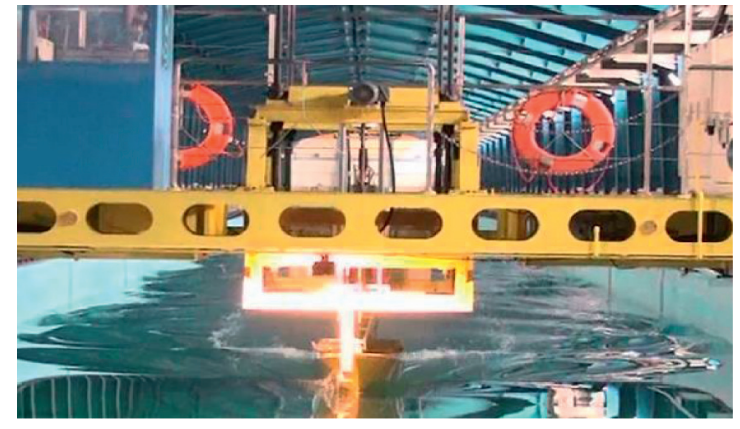

(b)

Figure 3: (a) Location of cameras and sensors on the carrier; (b) towing tank during the tests.

TABLE 5: Measured parameters of the nonstep model.

\begin{tabular}{lccccc}
\hline$V(\mathrm{~m} / \mathrm{s})$ & $\mathrm{Fr}_{B}$ & Rise-up $(\mathrm{mm})$ & $Z / V^{0.3}$ & $\tau(\mathrm{deg})$ & $R_{T}(\mathrm{~N})$ \\
\hline 1 & 0.43 & -1.78 & -0.004 & 2.47 & 7.8 \\
2 & 0.86 & -8.67 & -0.019 & 3.73 & 52.97 \\
3 & 1.29 & 4.03 & 0.009 & 6.17 & 113.3 \\
4 & 1.72 & 26.71 & 0.06 & 6.77 & 0.009 \\
5 & 2.15 & 52.61 & 0.118 & 7.39 & 0.134 \\
6 & 2.58 & 70.26 & 0.158 & 6.63 & 136.7 \\
7 & 3.01 & 81.54 & 0.184 & 5.81 & 0.151 \\
8 & 3.44 & PORP. & PORP. & PORP & 0.162 \\
\hline
\end{tabular}

considered models is done based on the relations given in Table 8.

The calculations performed for the single-step models are given in Table 9. These quantities are calculated based on percentage of the total drag coefficient.

\section{Numerical Setup}

The numerical simulation procedure is described in this section.

4.1. Governing Equation of Numerical Simulation. The unsteady Reynolds-averaged Navier-Stokes equations for an unsteady three-dimensional flow include continuity equation and momentum equation, which can be written as follows:

$$
\begin{gathered}
\frac{\partial U_{i}}{\partial x_{i}}=0 \\
\frac{\partial U_{i}}{\partial t}+\frac{\partial\left(U_{i} U_{j}\right)}{\partial x_{j}}=-\frac{1}{\rho} \frac{\partial p}{\partial x_{i}}+\frac{\partial}{\partial x_{j}}\left[v\left(\frac{\partial U_{i}}{\partial x_{j}}+\frac{\partial U_{j}}{\partial x_{i}}\right)\right]-\frac{\partial \overline{u_{i}^{\prime} u_{j}^{\prime}}}{\partial x_{j}}
\end{gathered}
$$

where $U_{i}$ is the averaged speed, $x_{i}$ is the spatial coordinates, $u_{i}^{\prime}$ is the oscillating speed, $\rho$ is the density of the fluid, $p$ is the averaged pressure, and $v$ is the kinematic viscosity. It should be noted that Reynolds stress tensor, $\left(\overline{u_{i}^{\prime} u_{j}^{\prime}}\right)$, can be expressed, based on Boussinesq approximation, as follows:

$$
\overline{u_{i}^{\prime} u_{j}^{\prime}}=v_{t}\left(\frac{\partial U_{i}}{\partial x_{j}}+\frac{\partial U_{j}}{\partial x_{i}}\right)+\frac{2}{3} \delta_{i j} k,
$$

where $v_{t}$ is the vortical viscosity using in standard $k$-epsilon turbulence model, which can be calculated through $v_{t}=C_{\mu}\left(k^{2} / \varepsilon\right)$. Parameter $C_{\mu}$ is an empirical constant, which is equal to 0.09 . The symbol $k$ represents the turbulent kinematic energy, and $\epsilon$ expresses the dispersion rate of $k$. These two parameters are calculated in standard $k$-epsilon turbulence model. Standard $k$-epsilon is a two-equation model, which introduces the following transition equations to express the turbulent properties of the flow:

$$
\begin{aligned}
& \frac{\partial k}{\partial t}+\frac{\partial}{\partial x_{i}}\left(k \overline{U_{i}}\right)=\frac{\partial}{\partial x_{i}}\left[\left(v+\frac{v_{t}}{\sigma_{k}}\right) \frac{\partial k}{\partial x_{i}}\right]+P_{k}-\varepsilon, \\
& \frac{\partial \varepsilon}{\partial t}+\frac{\partial}{\partial x_{i}}\left(\varepsilon \overline{U_{i}}\right)=\frac{\partial}{\partial x_{j}}\left[\left(v+\frac{v_{t}}{\sigma_{\varepsilon}}\right) \frac{\partial \varepsilon}{\partial x_{j}}\right]+\frac{\varepsilon}{k}\left(C_{\varepsilon 1} P_{k}-C_{\varepsilon 2} \varepsilon\right) .
\end{aligned}
$$


TABLE 6: Measured parameters of the single-step model.

\begin{tabular}{|c|c|c|c|c|c|c|}
\hline$V(\mathrm{~m} / \mathrm{s})$ & $\mathrm{Fr}_{B}$ & Rise-up (mm) & $Z / V^{0.3}$ & $\tau(\mathrm{deg})$ & $R_{T}(N)$ & $R_{T} / \Delta$ \\
\hline 1 & 0.43 & -1.321 & -0.003 & 3 & 9.8 & 0.01 \\
\hline 2 & 0.86 & -7.061 & -0.016 & 4.21 & 58.2 & 0.068 \\
\hline 3 & 1.29 & 5.82 & 0.013 & 6.8 & 117.5 & 0.139 \\
\hline 4 & 1.72 & 27.20 & 0.061 & 6.7 & 130.5 & 0.154 \\
\hline 5 & 2.15 & 47.94 & 0.108 & 6.5 & 134.8 & 0.159 \\
\hline 6 & 2.58 & 66.89 & 0.151 & 5.81 & 131 & 0.155 \\
\hline 7 & 3.01 & 76.7 & 0.173 & 5.15 & 132.8 & 0.157 \\
\hline 8 & 3.44 & 80.2 & 0.181 & 4.21 & 136.8 & 0.162 \\
\hline
\end{tabular}

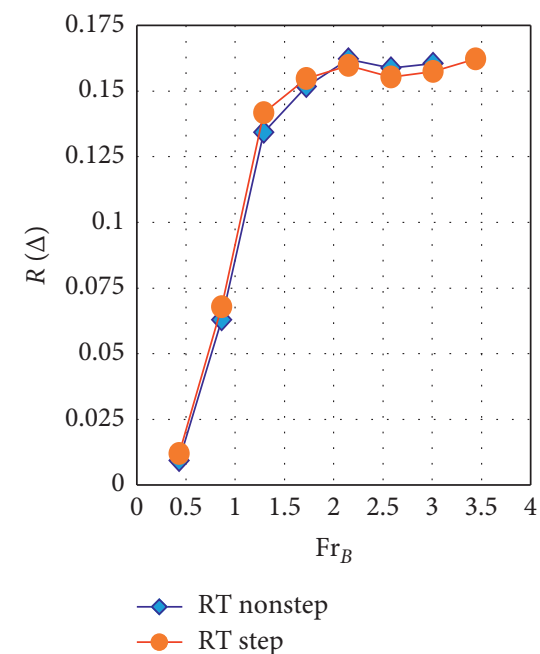

(a)

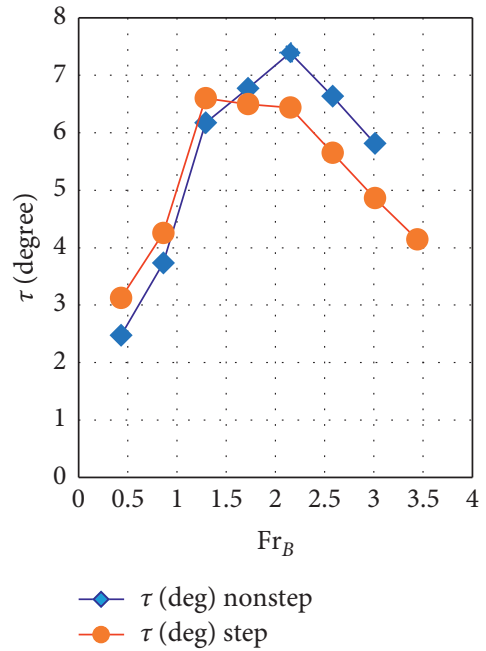

(b)

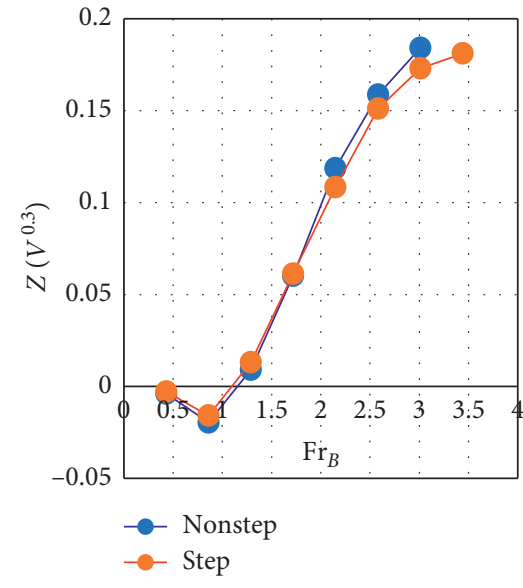

(c)

Figure 4: Diagrams of (a) resistance, (b) trim, and (c) heave versus speed for the two considered models in calm water.

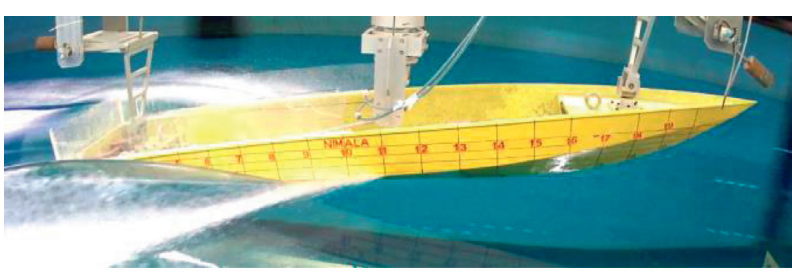

(a)

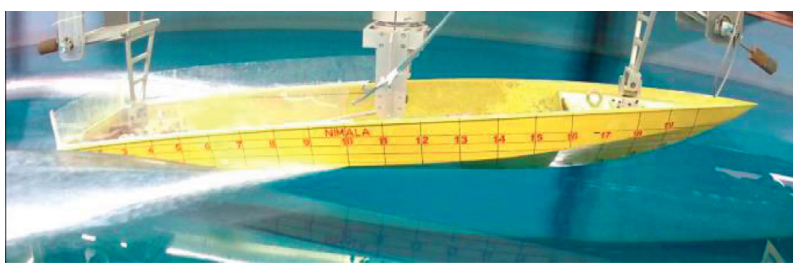

(c)

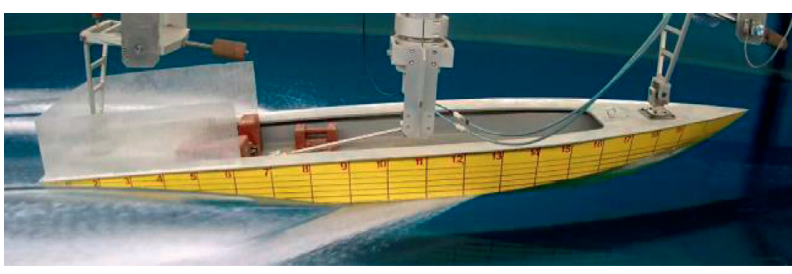

(b)

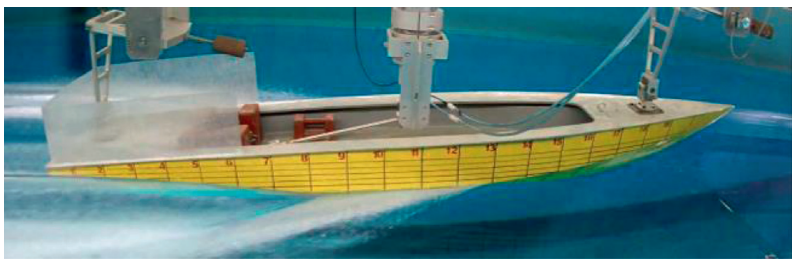

(d)

Figure 5: Comparison of models at (a) $6 \mathrm{~m} / \mathrm{s}$ speed, nonstep; (b) $6 \mathrm{~m} / \mathrm{s}$ speed, stepped model; (c) $7 \mathrm{~m} / \mathrm{s}$ speed, nonstep; (d) $7 \mathrm{~m} / \mathrm{s}$ speed, stepped model.

These two equations include four adjustable constants, which include $C_{\varepsilon 1}=1.44, C_{\varepsilon 2}=1.92$, and turbulent Prandtl numbers of $k$ and $\epsilon$ are $\sigma_{\varepsilon}=1.3$, and $\sigma_{k}=1$.

4.2. The Volume of Fluid (VOF) Model. This model uses a concept called equivalent fluid. It is assumed that the velocity and pressure of two-phase fluid are the same. This assumption ultimately leads to solution of the governing equations of momentum and transition, described in the previous section, as a single-phase flow.

In this study, no phase change between fluids is allowed, implying that air cannot be dissolved in water or water does 
TABLE 7: Error values of measuring devices and model geometry.

\begin{tabular}{lc}
\hline Model construction & Error must be less than $1 \mathrm{~mm}$ \\
\hline Dynamometer & Must be less than 0.02 of the model weight \\
Speed tolerance & Shall be less than $\pm 2 \mathrm{~mm} / \mathrm{s}$ \\
Ambient temperature difference & Shall be less than $0.1^{\circ} \mathrm{C}$ \\
Maximum acceptable load & $10 \mathrm{~g}$ \\
The measurement error of the trim & Shall be less than one millimeter \\
\hline
\end{tabular}

TABLE 8: The practical relations in computing the total uncertainty.

\begin{tabular}{lc}
\hline Parameter & Formula \\
\hline Total friction in $15 \mathrm{deg}$ & $C_{T}^{15 \mathrm{deg}}=C_{T}^{\mathrm{Tw}}+\left(C_{F}^{15 \mathrm{deg}}-C_{F}^{\mathrm{Tw}}\right)(1+k)$ \\
Total friction & $C_{T}^{\mathrm{Tw}}=\left(R_{x}^{\mathrm{Tw}} \times g /(1 / 2) \rho V^{2} W_{S}\right)$ \\
Coefficient of friction & $C_{F}=(0.075) /\left(\log _{10} \mathrm{Re}-2\right)^{2}$ \\
Total drag uncertainty & $U_{\mathrm{CT}}^{2}=\left(U_{B \mathrm{CT}}\right)^{\mathrm{Tw}}+\left(K . U_{P_{\mathrm{CT}}}\right)^{2}$ \\
\hline
\end{tabular}

TABLE 9: Uncertainty of drag for single-step models.

\begin{tabular}{lccc}
\hline Velocity $(\mathrm{m} / \mathrm{s})$ & 6 & 7 & 8 \\
Uncertainty of drag (percent of total drag coefficient) & 0.3065 & 0.345 & 0.4318 \\
\hline
\end{tabular}

not evaporate in any way. In this case, the density and viscosity equations are defined as follows:

$$
\begin{gathered}
\mu=\sum_{i} \mu_{i} \alpha_{i}, \\
\rho=\sum_{i} \rho_{i} \alpha_{i},
\end{gathered}
$$

where the $\alpha_{\mathrm{i}}$ parameter is defined as follows:

$$
\begin{gathered}
\alpha_{i}=\frac{V_{i}}{V}, \\
\alpha_{\text {air }}+\alpha_{\text {water }}=\frac{V_{\text {air }}}{V}+\frac{V_{\text {water }}}{V}=1 .
\end{gathered}
$$

In order to simulate the free surface deformation in the present problem, a volumetric method is utilized, in a way that a transport equation is solved in each time step to calculate the volumetric ratio of two fluid phases (for example, air and water):

$$
\frac{\partial \alpha}{\partial t}+\vec{\nabla} \cdot(\alpha \vec{u})=0
$$

After solving the transport equation, the volumetric ratio, density, and viscosity of the equivalent fluid are calculated according to the following equation:

$$
\begin{aligned}
& \rho_{\text {eff }}=\alpha \rho_{1}+(1-\alpha) \rho_{2}, \\
& \nu_{\text {eff }}=\alpha \nu_{1}+(1-\alpha) \nu_{2} .
\end{aligned}
$$

These computed parameters are used in subsequent calculations.

\section{Numerical Simulations}

The hydrodynamic parameters are assessed in unsteady situation. The coupled pressure-velocity is modelled using SIMPLE method. The selected turbulence model is k-epsilon scheme. This simulation involves two degrees of freedom of heave and pitch motions. The Dynamic Fluid-Body Interaction (DFBI) is used to consider these two motions. Through this numerical model, RANS solver calculates the forces and moments exerted on the vessels. By solving the equations of motion, linear and angular velocities as well as accelerations of the vessel with respect to the coordinate system are computed. Due to the linear and angular motions of the models, a moving domain near the hull is necessary in the stationary domain. The two-phase flow containing water and air is simulated using VOF technique, which is based on tracking the free surface boundary. The deformation of grid through overset method is applied to capture the heave and pitch motions.

To establish the connectivity between the background and the overset regions, a two-step overset process takes place as described below. The cells around the interface of the overset mesh are identified and labelled as donor cells. Then, the cells in the background closest to the donor cells are identified and set as acceptor cells. These cells have to form a continuous layer of cells around the overset mesh. The background cells that are completely covered by the overset region are inactivated (the hole cutting process). The donor and acceptor cells transfer information between the meshes. Each acceptor cell has one or more donor cells. The set of donor cells depends on the interpolation option chosen and on the number of active cells in the donor region around the acceptor cell centroid [45]. According to previous numerical tests cases on planing hulls models [46], the linear interpolation scheme is the most suitable for the numerical results when comparing with the experimental data.

5.1. Computational Domain. The domain boundaries are considered far enough from the hull so that exerted flow on the vessel has no interaction with the boundaries. A conical control volume is applied over the models to increase the precision of the result and the quality of the Kelvin wave 
pattern behind the models. The center of this control volume is the free surface, which consists of finer mesh. The schematic view of the computational domain is illustrated in Figure 6. In this figure, length overall (LOA) of the model is $2.64 \mathrm{~m}$. Using the symmetry condition, only half of the model is simulated to significantly reduce the computational cost. All boundary conditions are presented in Table 10.

5.2. Mesh. In the present paper, the computational domain is meshed using trimmer hexahedral dynamic mesh. This type of meshing is usually applied for external flows. Figure 7 shows an overall close view and overset region of the generated mesh around the vessel.

A primary criterion for quality of the boundary layer mesh is $y^{+}$, which is related to the nondimensional distance of the first node of the grid from the surface of the models. On the other hand, finding the relation between different parameters in the fully turbulent region and walls necessitates some additional wall functions. In the Log law region, velocity varies logarithmically with respect to the $y^{+}$. According to ITTC recommendation, the value of $y^{+}$should not be higher than 300 in the use of $k$-epsilon turbulent model [47]. The $y^{+}$values at the bottom of nonstep and single-step models at the speeds of 8 and $9 \mathrm{~m} / \mathrm{s}$ are presented in Figure 8. As observed in this figure, all $y^{+}$are lower than 90 . These values are acceptable, according to the $k$-epsilon turbulence models [48].

5.3. Time-Step and Mesh Study. Selection of time-step $(\Delta t)$ is achieved using Equation (12), which is according to the recommendation of ITTC-2008. This time-step is expressed in terms of length $(l)$ and velocity $(V)$ [45]. Here, $l$ is assumed to be the wetted length of models' keel $\left(L_{K}\right)$.

$$
\Delta t=0.01 \sim 0.005 \frac{l}{V},
$$

On the other hand, the Courant number (CFL) as a function of time-step, velocity, and minimum length of the element in flow direction, should be less than 1. Courant number is defined as follows:

$$
C=\frac{V_{i} \cdot \Delta t}{\Delta X_{i}} \leq C_{\max },
$$

where $\Delta x$ is the distance between the nearest cell, i.e., the smallest cell and the surface of the models. However, the value of Courant number is a function of Froude number, as well.

Validation of the computed resistance, trim, and rise-up of nonstep and single-step models is accomplished using three different structured trimmer, hexahedral, and dynamic meshes. The calculated total resistance of single-step models versus the number of cells at $8 \mathrm{~m} / \mathrm{s}$ speed is presented in Table 11. As observed in this table, by increasing the number of cells to more than $1,700,000$, the change in resistance is negligible. Hence, this number of cells seems appropriate for conducting the targeted simulations.
5.4. Uncertainty of Grid and Validation. Based on ITTC 2008 , the uncertainty of numerical simulation, $U_{\mathrm{SN}}$, includes three different types of uncertainties $\left(U_{I}\right)$, grid $\left(U_{G}\right)$, and time-step $\left(U_{\mathrm{TS}}\right)$ as in

$$
U_{\mathrm{SN}}^{2}=U_{I}^{2}+U_{G}^{2}+U_{\mathrm{TS}}^{2}
$$

Among the different uncertainties mentioned above, grid uncertainty is the most influential. The Grid Convergence Index (GCI) is calculated for three different meshes and presented in Table 9. In the present paper, $R_{K}=\left(\varepsilon_{21_{K}} / \varepsilon_{32_{K}}\right)$ is in the range of $0<R_{K}<1$. Therefore, it satisfies the monotonic convergence condition [46]. Through this method, the average of the apparent order can be calculated as follows:

$$
P_{\mathrm{avg}}=\frac{1}{\ln \left(r_{21}\right)}|\ln | \frac{\varepsilon_{32}}{\varepsilon_{21}}\left|+q\left(P_{\mathrm{avg}}\right)\right| \text {, }
$$

where

$$
q\left(P_{\mathrm{avg}}\right)=\ln \left(\frac{r_{21}^{P_{\text {avg }}}-s}{P_{32}-s}\right) .
$$

In the present paper, the mesh modifying factors are $r_{21}=\sqrt{2}$ and $r_{32}=\sqrt{2}$. In addition, for the computed parameter of resistance, shown by $\varphi$, there are two relations, $\varepsilon 21=\varphi 2-\varphi 1$ and $\varepsilon 32=\varphi 3-\varphi 2$. The extrapolated value, defined approximated relative error, extrapolated relative error, and fine-grid convergence index in GCI are defined in Table 12 .

The values of these defined parameters, required to obtain the hydrodynamics resistance of single-step model, are presented in Table 13.

Figure 9 compares the flow around the two vessels in the numerical and experimental mode. The comparisons are made at $7 \mathrm{~m} / \mathrm{s}$ speed.

Based on Table 14, validation is conducted against the experimental model. In Table 14, comparison is made between numerical and experimental results of two models at 6 and $7 \mathrm{~m} / \mathrm{s}$ speeds. Based on the comparison between the experimental measurements and numerical results for single-step and nonstep models displayed in Table 14, good agreement is observed.

\section{Simulation Results}

The computed trim, heave, and resistance of nonstep models at $9 \mathrm{~m} / \mathrm{s}$ speed are illustrated in Figure 10 . Due to the oscillations of these results, the occurrence of porpoising is anticipated. In addition, using the cameras attached to the carriage, the porpoising of this model at $9 \mathrm{~m} / \mathrm{s}$ speed is quite apparent in Figure 11.

As evident in Figure 8, the oscillations of drag, trim, and heave range from 70 to 80 Newtons (half body), 3.5 to 4.5 degrees, 90 to $100 \mathrm{~cm}$, respectively. The distance between the model's bow and the potentiometer at $9 \mathrm{~m} / \mathrm{s}$ speed is shown in Figure 11. Based on two different snapshots presented in Figure 11, this distance changes rapidly. 


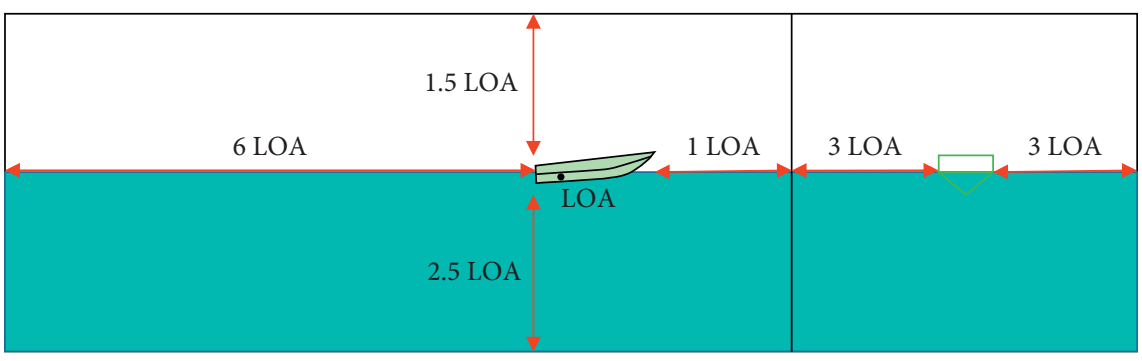

Figure 6: Schematic of the computational domain.

TABle 10: Prescribed boundary conditions.

\begin{tabular}{lccc}
\hline Boundary & & Variable & $\alpha$ \\
\hline Inlet water & $U$ & $(\partial \mathbf{P} / \partial \mathbf{n})=0$ & 0 \\
Inlet air & $U=U i+0 j$ & $(\partial \mathbf{P} / \partial \mathbf{n})=0$ & 1 \\
Outlet & $U=U i+0 j$ & $\mathbf{P}=0$ & $(\partial \alpha / \partial \mathbf{n})=0$ \\
Boat & $(\partial \mathbf{U} / \partial \mathbf{n})=0$ & $(\partial \mathbf{P} / \partial \mathbf{n})=0$ & $(\partial \alpha / \partial \mathbf{n})=0$ \\
Up & $\mathbf{U}=0$ & $\mathbf{P}=0$ & $(\partial \alpha / \partial \mathbf{n})=0$ \\
Down & $(\partial \mathbf{U} / \partial \mathbf{n})=0$ & $(\partial \mathbf{P} / \partial \mathbf{n})=0$ & $(\partial \alpha / \partial \mathbf{n})=0$ \\
\hline
\end{tabular}
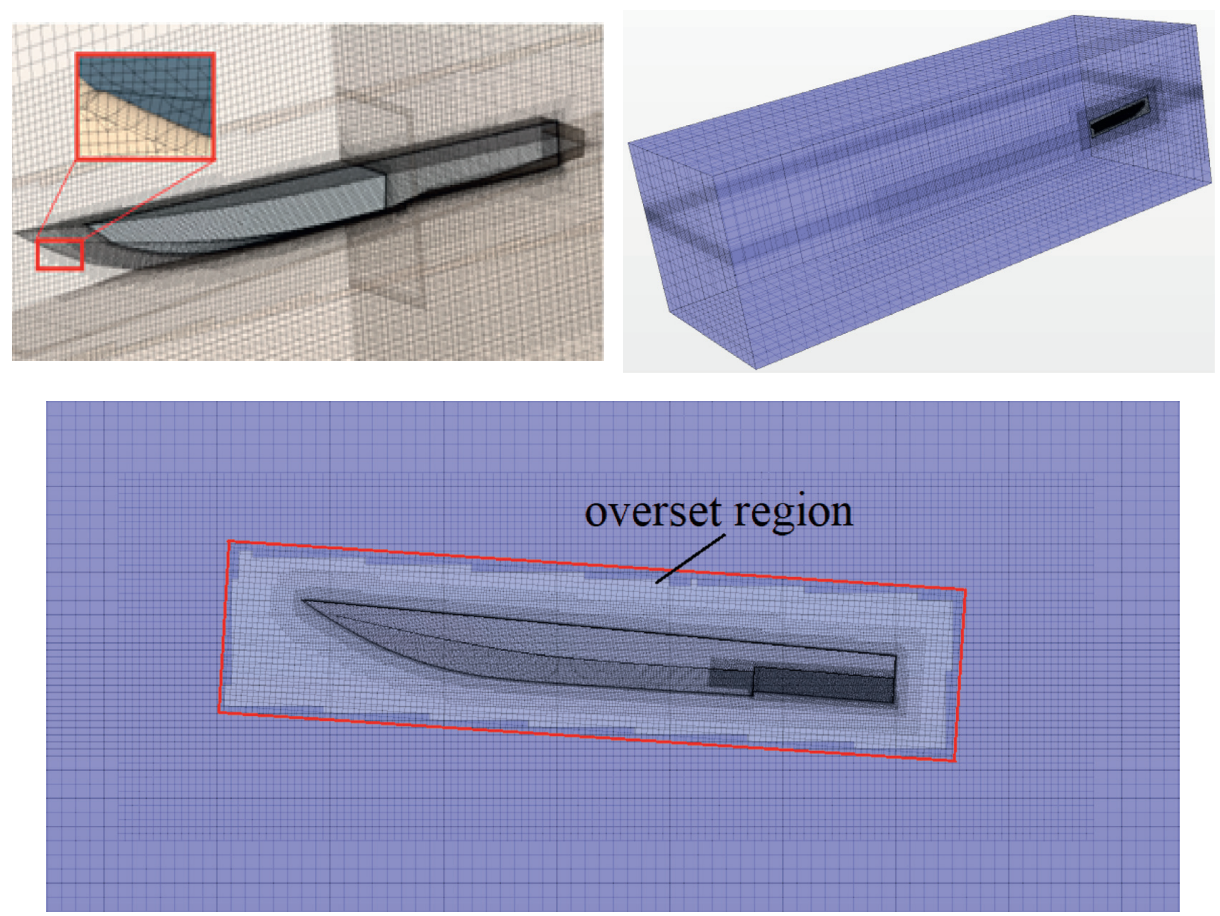

Figure 7: Overall close view of the mesh around the vessel.

6.1. Trim, Rise-Up, and Resistance. After validation of the results, the effects of longitudinal location of the step are investigated. As observed in Table 15, the distance between step and stern of the single-step vessels, which have been studied so far, ranges from 20 to 50 percent of the length of the vessels $\left(\left(l_{s} / \mathrm{LOA}\right) \times 100\right)$. Heights of the vessel steps are also presented as a percentage of the vessels' beam $\left(\left(H_{S} / B\right) \times\right.$ 100) in Table 13.

Based on these studies, the proper distance of a transverse step to the stern is in the range of 19 to 50 percent of the vessel's length. In the present paper, step height is also considered as 5 percent of the vessel's beam. However, only the effects of longitudinal location of the step are hereby investigated. Hence, the longitudinal location of step and vessel speed are variable, and the location of center of gravity and height of the step are fixed. Table 16 presents the values of resistance, trim, and rise-up of 10 models at 8, 9, and $10 \mathrm{~m} / \mathrm{s}$ speeds.

The computed values of trim, heave, and resistance in terms of longitudinal distance of step from the transom at 

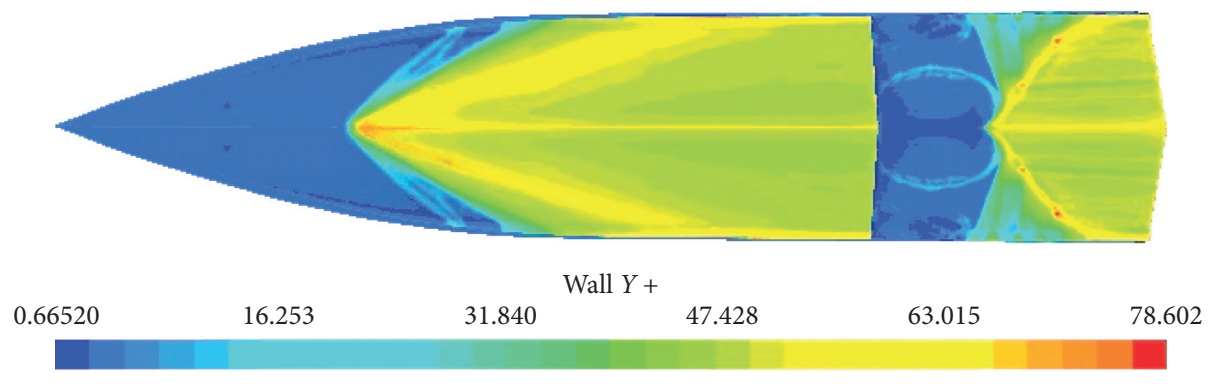

(a)

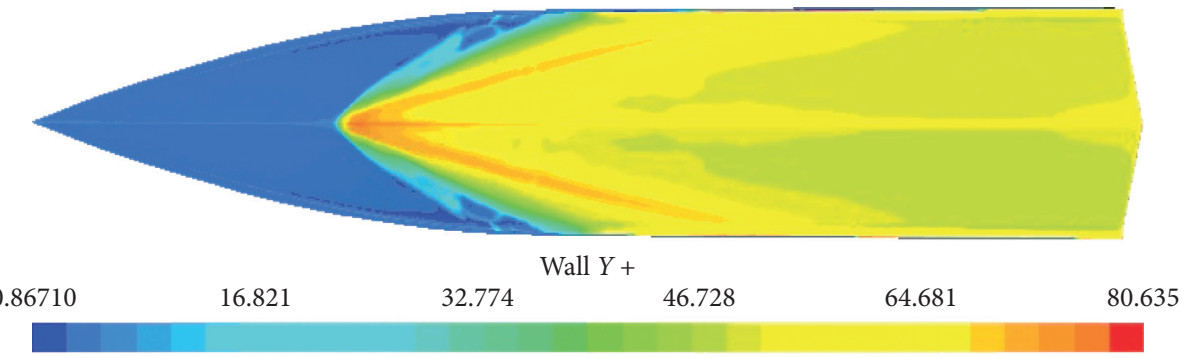

(b)

Figure 8: $y^{+}$values of (a) single-step at $8 \mathrm{~m} / \mathrm{s}$ and (b) nonstep model at $9 \mathrm{~m} / \mathrm{s}$.

TABLE 11: Difference percentage of hydrodynamic criteria by change in mesh resolution.

\begin{tabular}{lcc}
\hline Grid accumulation & Num. mesh $\times 10^{5}$ & Numerical drag $(N)$ \\
\hline Coarse & 8 & 130.4 \\
Medium & 17 & 136 \\
Fine & 20 & 136.36 \\
Difference percentage & Coarse to medium & $4 \%$ \\
\hline
\end{tabular}

TABLE 12: Terms involved in CGI calculation.

\begin{tabular}{lc}
\hline Parameter & Defining the parameter \\
\hline$\varphi_{\text {ext }}^{32}=\left(r_{32}\right.$ avg $\left.\varphi_{2}-\varphi_{3}\right) /\left(r_{32}^{P_{\text {avg }}}-1\right)$ & Extrapolated value \\
$e_{a}^{32}=\left|\left(\varphi_{2}-\varphi_{3}\right) / \varphi_{2}\right|$ & Defined approximated relative error \\
$e_{\text {ext }}^{32}=\left|\left(\varphi_{\text {ext }}^{23}-\varphi_{2}\right) / \varphi_{\text {ext }}^{23}\right|_{P_{\text {avg }}}$ & Extrapolated relative error \\
$G C I_{\text {fine }}^{32}=\left(1.25 e_{a}^{32}\right) /\left(r_{32}-1\right)$ & Fine-grid convergence index \\
\hline
\end{tabular}

TABLE 13: CGI method for hydrodynamics resistance of single-step models.

\begin{tabular}{lcc}
\hline Parameter & Hydrodynamics resistance & Unit \\
\hline$\varphi_{1}$ & 114 & $\mathrm{~N}$ \\
$\varphi_{2}$ & 123 & $\mathrm{~N}$ \\
$\varphi_{3}$ & 129 & $\mathrm{~N}$ \\
$P$ avg & 4.6 & - \\
$\varphi_{\text {ext }}^{32}$ & 189.35 & $\mathrm{~N}$ \\
$e_{a}^{32}$ & $0.224 \%$ & Nondimensionalized \\
$e_{\text {ext }}^{32}$ & $0.09 \%$ & Nondimensionalized \\
$\mathrm{GCI}_{\text {fine }}^{32}$ & $5.854 \%$ & Nondimensionalized \\
\hline
\end{tabular}

different speeds are presented in two diagrams in Figures 12 and 13 .

As evident in Figures 12 and 13, through an increase in the longitudinal distance of the step from the transom, the resistance increases and trim decreases. The red and blue lines in Figures 12(a) and 13(a) indicate the resistance increase and trim reduction, respectively. Based on these figures, as the longitudinal distance between step and transom increases, the trim is reduced due to the fixed height and center of gravity location of the models. The direct effect 


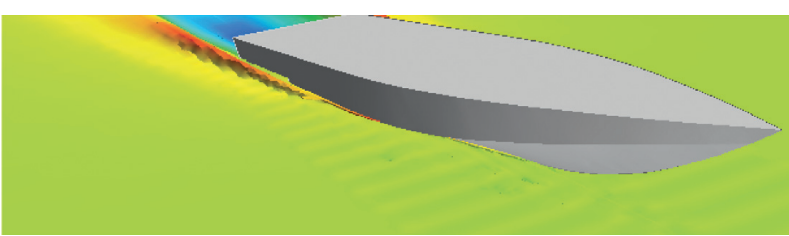

(a)

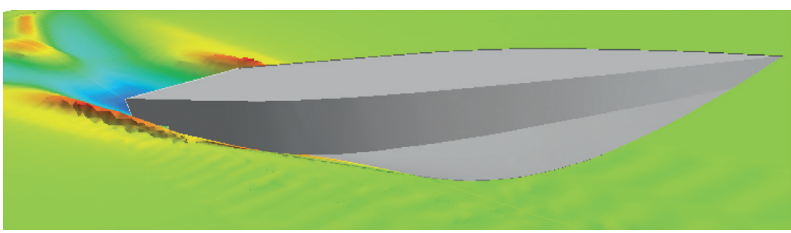

(c)

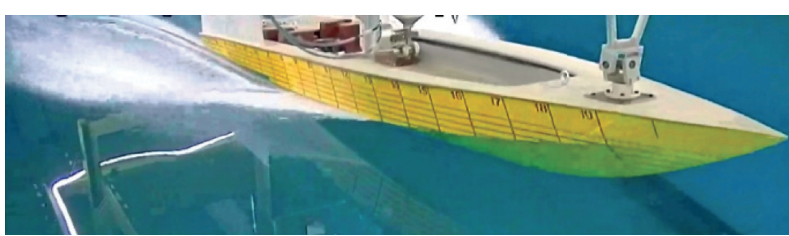

(b)

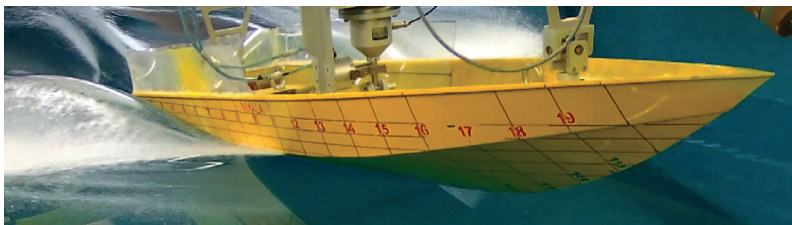

(d)

Figure 9: Comparison of flow around two models in the numerical and experimental mode at $7 \mathrm{~m} / \mathrm{s}$ speed: (a) the numerical model of a single step, (b) the experimental model of a single step, (c) the numerical model without a step, and (d) the experiment model without a step.

TABLE 14: Comparison between the experimental measurements and numerical data for nonstep and single-step models.

\begin{tabular}{lcccccccccc}
\hline \multirow{2}{*}{ Model } & \multirow{2}{*}{ Velocity $(\mathrm{m} / \mathrm{s})$} & \multicolumn{3}{c}{ Drag $(\mathrm{N})$} & \multicolumn{3}{c}{ Trim (degree) } & \multicolumn{3}{c}{ Rise-up (mm) } \\
& & Exp & Num & Error (\%) & Exp & Num & Error (\%) & Exp & Num & Error (\%) \\
\hline Nonstep & 6 & 133.9 & 130.4 & 2 & 6.63 & 6.1 & 8 & 70.26 & 66 & 5 \\
Nonstep & 7 & 135.3 & 132.4 & 2 & 5.81 & 5.2 & 9 & 81.54 & 75 & 8 \\
Single step & 6 & 131 & 126.5 & 3 & 5.81 & 5.4 & 7 & 66.89 & 70 & 6 \\
Single step & 7 & 132.8 & 128.5 & 3 & 5.15 & 4.5 & 12 & 76.7 & 81 & 7 \\
\hline
\end{tabular}

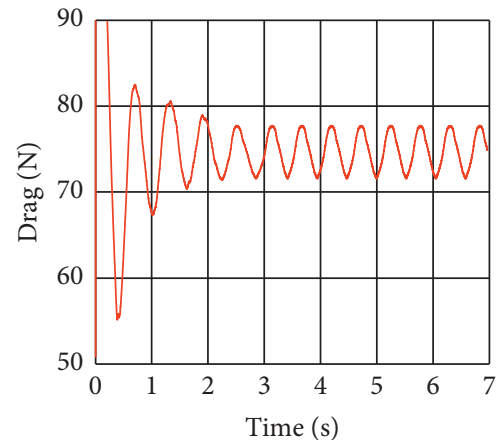

(a)

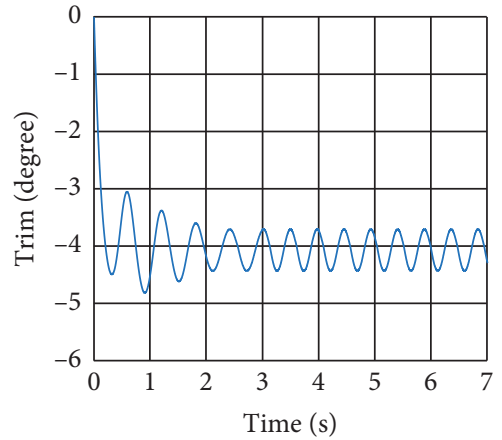

(b)

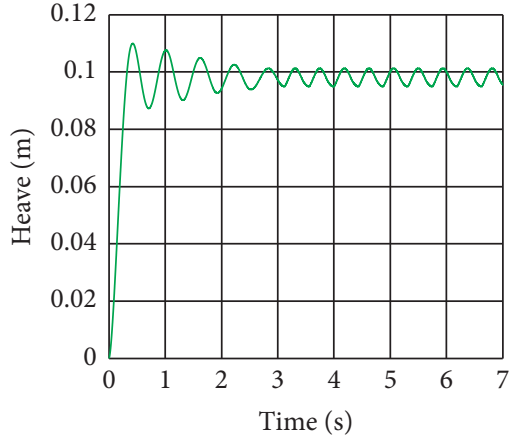

(c)

Figure 10: Drag, trim, and heave of model A at $9 \mathrm{~m} / \mathrm{s}$ speed.

of the longitudinal position of step on the rise-up is illustrated in Figures 12(b) and 13(b). By increasing the longitudinal distance of the step from the transom, the rise-up decreases. As speed increases, the stability of the models is reduced. At $10 \mathrm{~m} / \mathrm{s}$ speed, the first two cases, which had the lowest distance of the step to the transom, become unstable. This instability is due to the increase in trim and lack of sufficient wetted surface area in the second hull. The optimum location ratio, which causes the lowest drag and stability for the vessel, is in the range of 23 to 25 . All investigated cases can be categorized as the following three regions.

(1) Unstable regions with trim increase
(2) Stable regions with optimized trim

(3) Stable regions along with trim reduction and drag increase

The three sections' domains vary with speed change and are function of trim angle and the wetted surface area of the stern and bow of the models. The values of trim, rise-up, and resistance of cases 3, 4, and 5 are presented in Figure 14, at three different speeds. The steps of these three models are located at the longitudinal distances of 25 to 29 percent of vessel's length to the transom.

As observed in Figure 14, by increasing the speed, the resistance increases as well. This is due to the trim reduction caused by the rise of the lift of the stern and expanding of the 

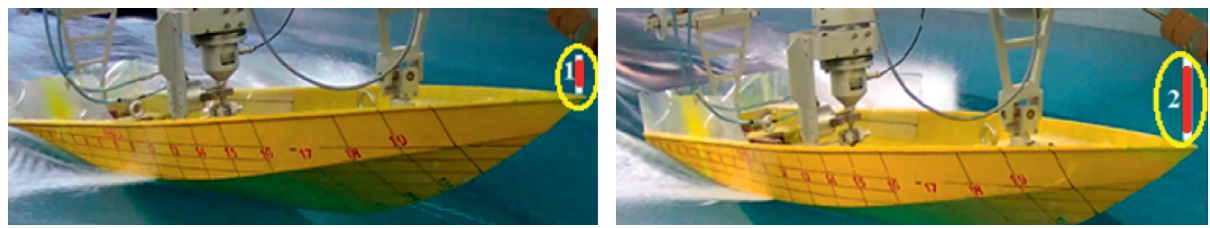

Figure 11: Oscillations caused by porpoising at the speed of $9 \mathrm{~m} / \mathrm{s}$.

TABLE 15: Longitudinal distance from step to transom and the height of steps in the previous exmperimental research.

\begin{tabular}{lcc}
\hline Researcher & LS/LOA*100 & Hs/B* 100 \\
\hline Rodeston 1953 & 50 & 5.6 \\
Filing 1993 & 50 & 20 \\
Kartinen 1994 & 38 & 10 \\
Becker 2008 & 35 & 2 \\
White 2010 & 33 & 7 \\
Garland 2012 & 33 & 4 \\
Taunton 2012 & 32 & 4 \\
Present paper & 25 & 5 \\
\hline
\end{tabular}

TABLE 16: Computed resistance, trim, and heave for different longitudinal locations of step at three different speeds.

\begin{tabular}{|c|c|c|c|c|c|c|c|c|c|c|c|}
\hline \multirow[b]{2}{*}{ Case } & \multirow[b]{2}{*}{$\begin{array}{l}\text { Distance of transom } \\
\qquad(\mathrm{mm})\end{array}$} & \multirow[b]{2}{*}{$($ Lstep/LOA $) \times 100$} & \multicolumn{3}{|c|}{$8 \mathrm{~m} / \mathrm{s}$} & \multicolumn{3}{|c|}{$9 \mathrm{~m} / \mathrm{s}$} & \multicolumn{3}{|c|}{$10 \mathrm{~m} / \mathrm{s}$} \\
\hline & & & $R / \Delta$ & $\begin{array}{l}\text { Trim } \\
(\operatorname{deg})\end{array}$ & $\mathrm{Z} / \mathrm{V}^{0.33}$ & $R / \Delta$ & $\begin{array}{l}\text { Trim } \\
(\mathrm{deg})\end{array}$ & $Z / V^{0.33}$ & $R / \Delta$ & $\begin{array}{l}\text { Trim } \\
(\mathrm{deg})\end{array}$ & $Z / V^{0.33}$ \\
\hline 1 & 500 & 19 & 0.1616 & 4.5 & 0.191 & 0.1652 & 3.8 & 0.1963 & $\mathrm{P}$ & $\mathrm{P}$ & $\mathrm{P}$ \\
\hline 2 & 620 & 23 & 0.16116 & 4.5 & 0.189 & 0.1652 & 3.8 & 0.196 & $\mathrm{P}$ & $\mathrm{P}$ & $\mathrm{P}$ \\
\hline 3 & 670 & 25 & 0.16116 & 4.3 & 0.185 & 0.1636 & 3.78 & 0.1941 & 0.172 & 3.55 & 0.20 \\
\hline 4 & 720 & 27 & 0.16116 & 4.09 & 0.178 & 0.1683 & 3.62 & 0.191 & 0.174 & 3.19 & 0.19 \\
\hline 5 & 770 & 29 & 0.1659 & 4 & 0.176 & 0.1668 & 3.5 & 0.189 & 0.1768 & 3.1 & 0.194 \\
\hline 6 & 820 & 31 & 0.1669 & 3.8 & 0.171 & 0.1683 & 3.4 & 0.186 & 0.180 & 2.8 & 0.191 \\
\hline 7 & 870 & 33 & 0.1673 & 3.78 & 0.169 & 0.1683 & 3.3 & 0.183 & 0.1826 & 2.6 & 0.185 \\
\hline 8 & 970 & 37 & 0.1680 & 3.7 & 0.164 & 0.1683 & 3.2 & 0.180 & 0.1884 & 2.6 & 0.182 \\
\hline 9 & 1120 & 42 & 0.1732 & 3.5 & 0.160 & 0.177 & 3.16 & 0.177 & 0.2039 & 2.5 & 0.18 \\
\hline 10 & 1320 & 50 & 0.1813 & 3.5 & 0.151 & 0.191 & 2.8 & 0.164 & 0.280 & 2.2 & 0.169 \\
\hline
\end{tabular}

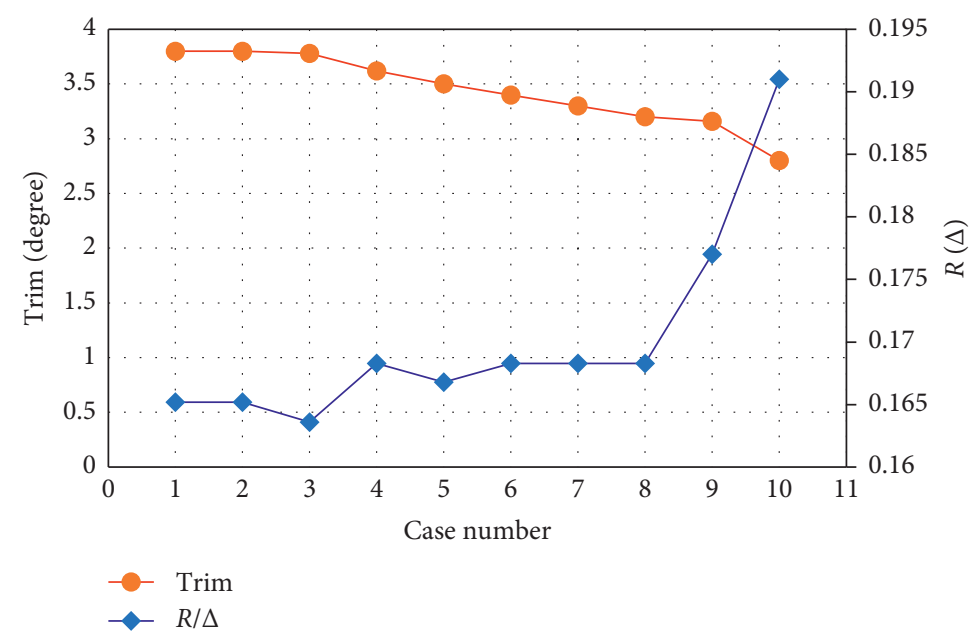

(a)

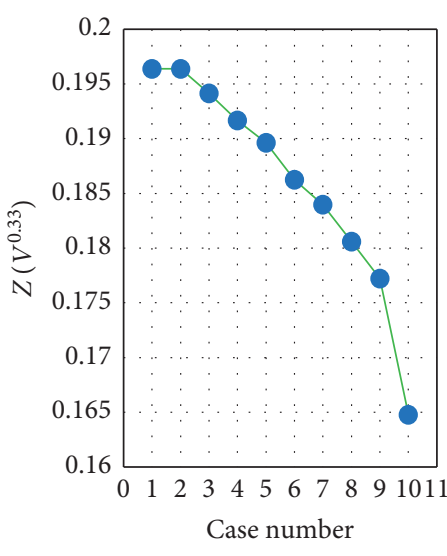

(b)

Figure 12: (a) Diagram of resistance and trim of cases 1 to 10 at the speed of $9 \mathrm{~m} / \mathrm{s}$; (b) diagram of heave at the speed of $9 \mathrm{~m} / \mathrm{s}$. 


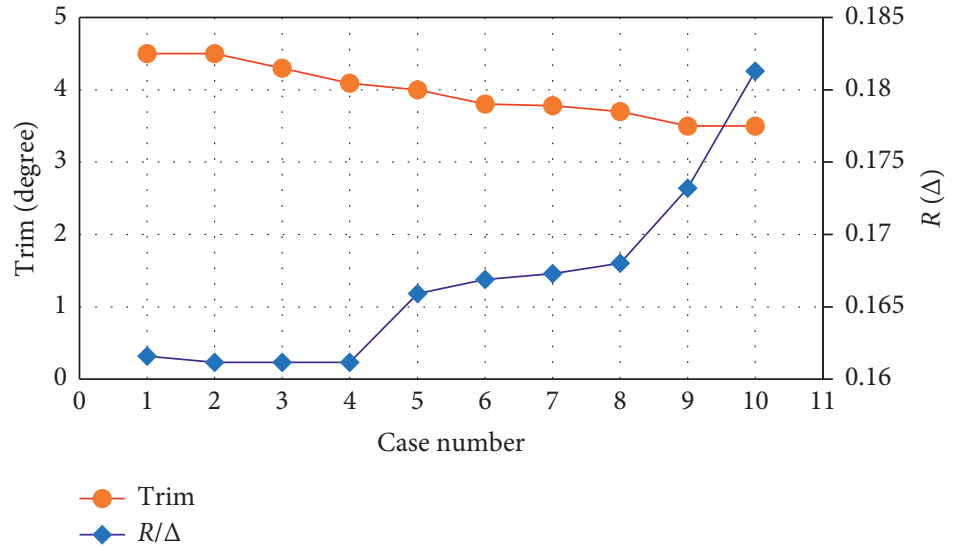

(a)

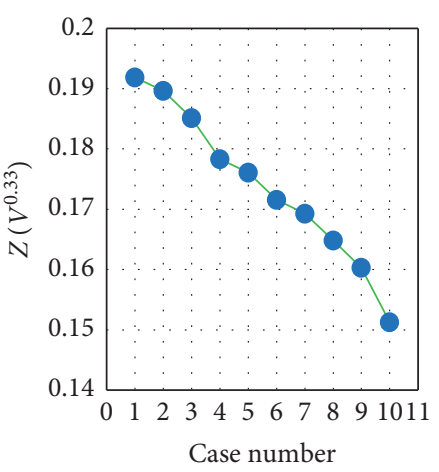

(b)

Figure 13: (a) diagram of resistance and trim of cases 1 to 10 at the speed of $8 \mathrm{~m} / \mathrm{s}$; (b) diagram of heave at the speed of $8 \mathrm{~m} / \mathrm{s}$.

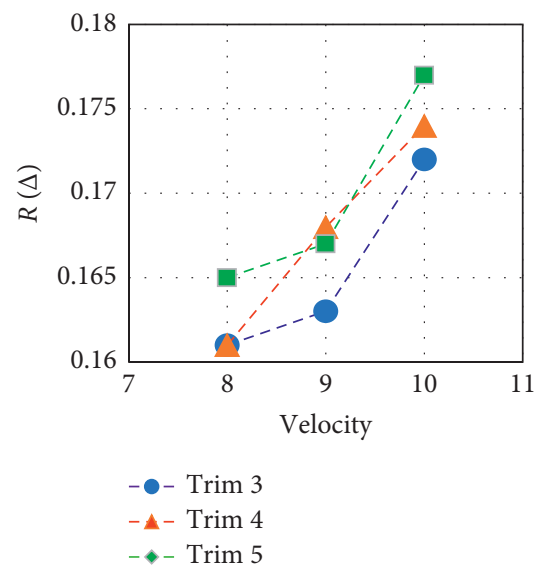

(a)

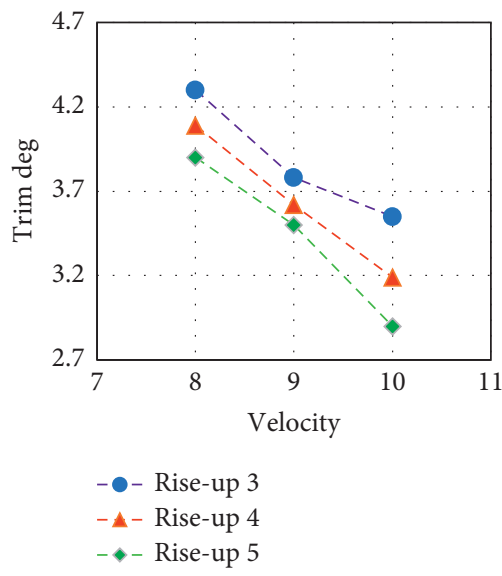

(b)

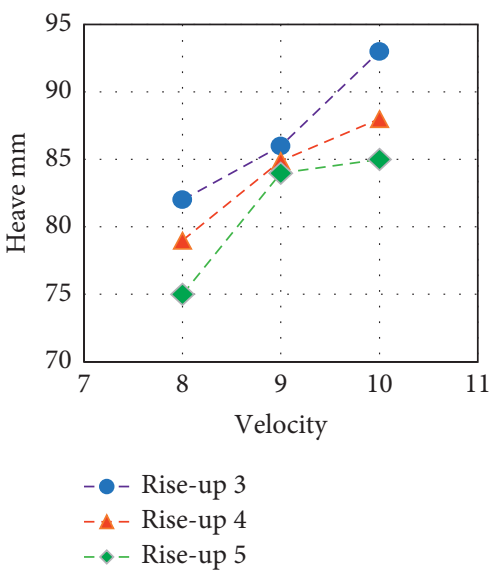

(c)

FIgURE 14: (a) Resistance of cases 3, 4, and 5, (b) trim of cases 3, 4, and 5, and (c) heave of cases 3, 4, and 5.

wetted surface area. The expansion of the wetted surface area in the first hull leads to an increase in frictional resistance. Increasing speed also increases the heave of the center of gravity due to the rise in the lift.

In the present paper, the optimization through the design of experiment (DOE) method is used to determine the longitudinal location of the steps, with the aim of minimizing the resistance, at velocities up to $10 \mathrm{~m} / \mathrm{s}$. Experimental design and optimization are tools that are used to systematically examine different types of problems that arise within, e.g., research, development, and production. Two important factors in DOE are the variables and their level of change. In a factorial design, the influences of all experimental variables, factors, and interaction effects on the response or responses are investigated. If the combinations of $k$ factors are investigated at two levels, a factorial design will consist of $2^{k}$ experiments. In some designs, the design levels are not the same on different factors. For this purpose, the multilevel method is used. In this paper, the multilevel method is used. In this method, all possible cases are considered. There are generally three models in test design to determine the response, linear method, linear method with interactions, and quadratic method. The multilevel method is actually a method of considered interactions.

$$
Y=\beta_{0}+\sum_{i=1}^{k} \beta_{i} x_{i}+\sum \sum \beta_{i} x_{i} x_{j}
$$

In this equation, there are $\beta_{0}$ constant coefficients, $\beta_{i} x_{i}$ linear coefficients, and $\beta_{i} x_{i} x_{j}$ interactions. Speed is defined in three levels of 8,9 , and $10 \mathrm{~m} / \mathrm{s}$ and step length in 10 levels. According to the multilevel method, the number of possible experiments is hereby equal to 30 . Figure 15(a) shows the three-dimensional diagram of step location and velocity versus resistance. This diagram illustrates the effect of both step location and velocity parameters on the resistance of the model. The step location presented in Figures 15(a) and 15(b) is expressed as the ratio of the distance between step and transom to the overall length of the model. 

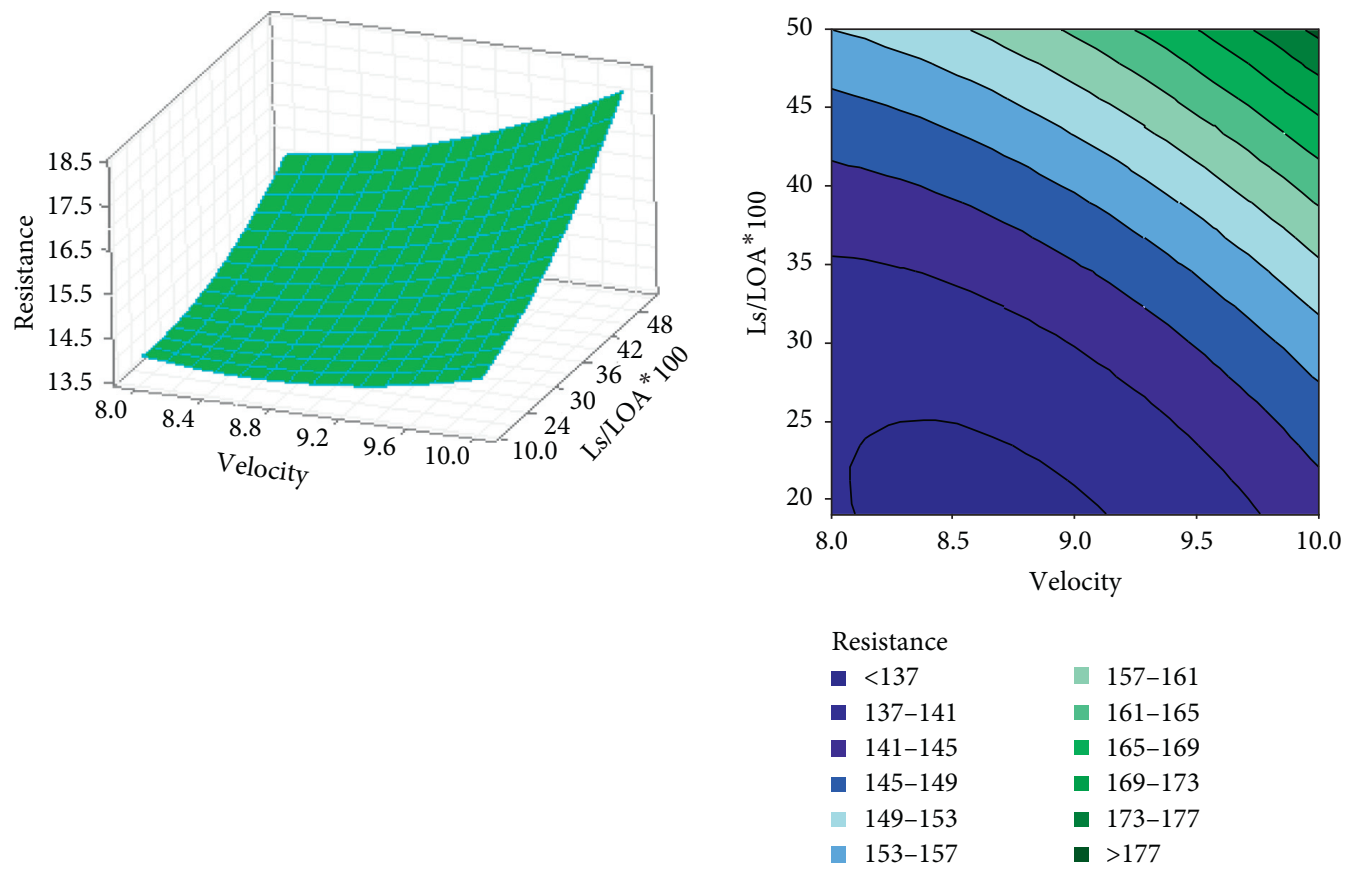

(a)

(b)

Figure 15: (a) Three-dimensional diagram of step location and velocity versus resistance; (b) the drag contour of the model.
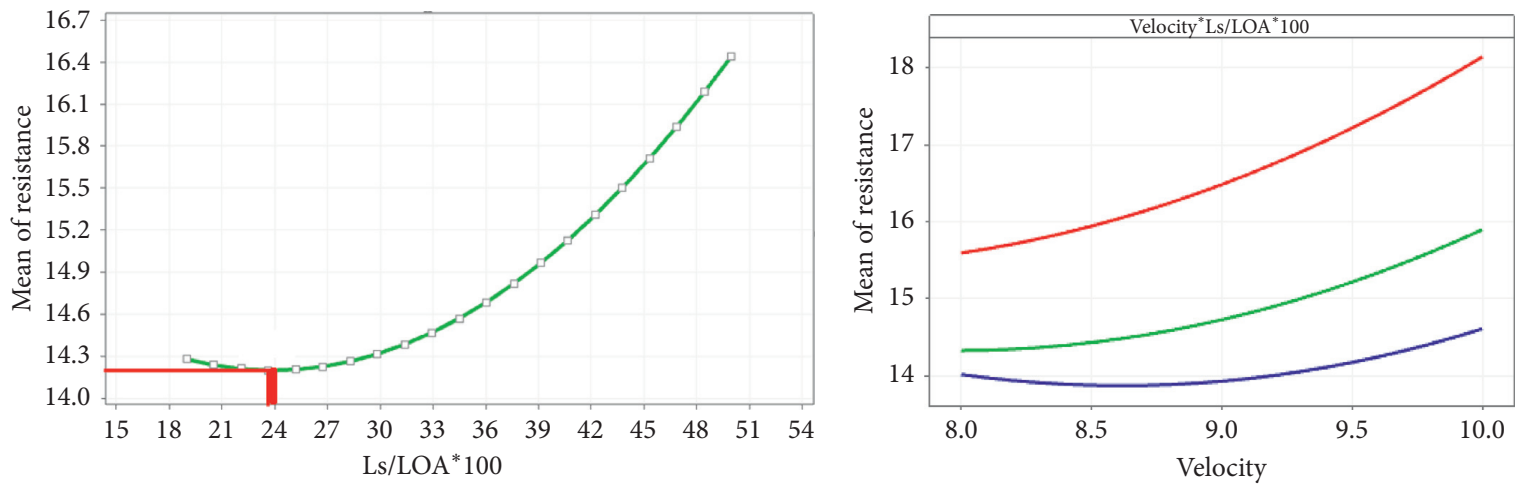

Ls/LOA* 100

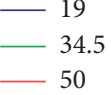

(a)

(b)

FIGURE 16: (a) Optimum location of the step; (b) velocity change versus resistance at three step location ratios of $19,34.5$, and 50 .

Figure 13(a) indicates that slope variation of the step location is larger than that of velocity. Hence, the resistance is more sensitive to the step location, compared to the velocity. On the other hand, the drag contour of the model versus step location and velocity is illustrated in Figure 15(b). The general trend of this contour indicates that drag variation at the location ratios $\left(\left(L_{s} / \mathrm{LOA}\right) \times 100\right)$ of 20 to 30 is relatively small. As this ratio increases, the drag variation increases, too.

Figure 16(a) shows the optimum location of the step, which is obtained through DOE method. The location ratio of 24 is the optimum location for the step and ensures the lowest drag and best stability for the vessel.

Figure 16(b) indicates the velocity change versus resistance at three location ratios of $19,34.5$, and 50 . The increasing or decreasing trend in each case can be described using different contours. Figure 17 displays the wetted surface area of case 3, respectively, at 8 and $9 \mathrm{~m} / \mathrm{s}$ speeds.

Tables 17 and 18 display the wetted surface area of the body for cases 3 and 4 . The area of these cases is shown in Figure 17. As the speed increases, the wetted surface of the second body decreases. 


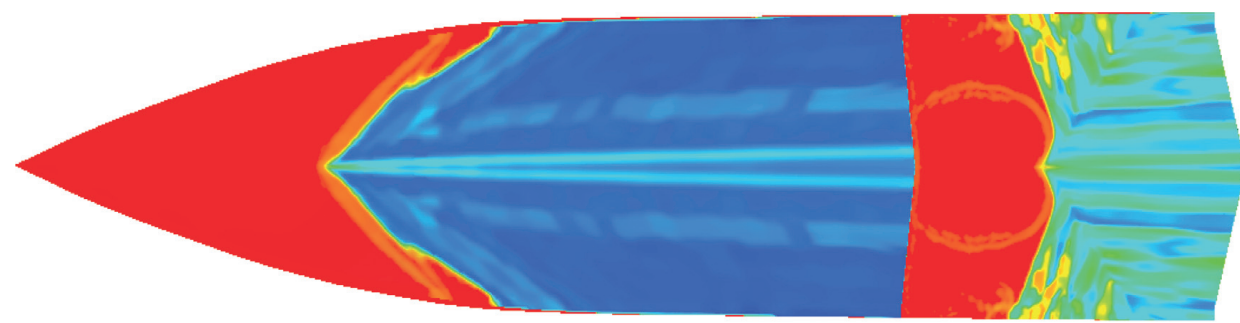

Volume fraction of water

0.00000

0.19956

0.39913

0.59869

0.79826

0.99782

(a)

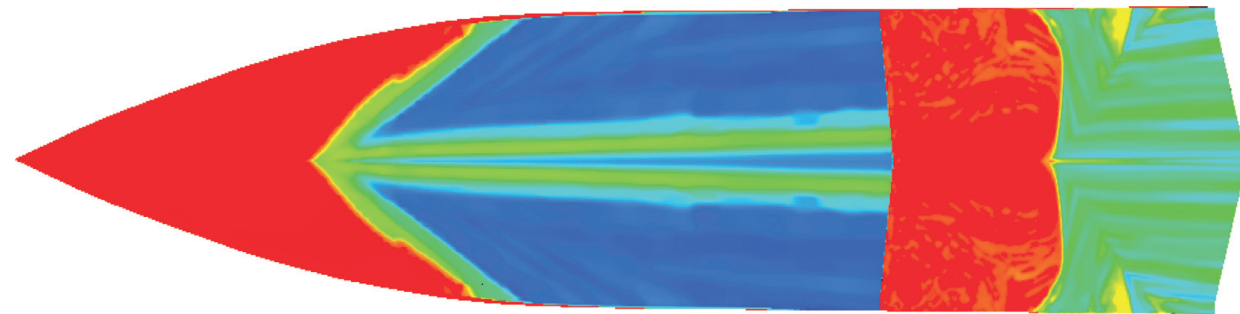

Volume Fraction of water

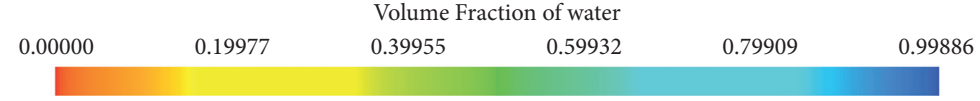

(b)

Figure 17: (a) Wetted surface area of case 3 at $8 \mathrm{~m} / \mathrm{s}$; (b) wetted surface area of case 3 at $9 \mathrm{~m} / \mathrm{s}$.

TABLE 17: Wetted surface area of the fore body.

\begin{tabular}{lccc}
\hline Case number & Area $\left(\mathrm{m}^{2}\right) ; 8 \mathrm{~m} / \mathrm{s}$ & Area $\left(\mathrm{m}^{2}\right) ; 9 \mathrm{~m} / \mathrm{s}$ & Area $\left(\mathrm{m}^{2}\right) ; 10 \mathrm{~m} / \mathrm{s}$ \\
\hline 3 & 0.62 & 0.63 & 0.66 \\
4 & 0.66 & 0.68 & 0.69 \\
\hline
\end{tabular}

TABLE 18: Wetted surface area of the second body.

\begin{tabular}{lccc}
\hline Case number & Area $\left(\mathrm{m}^{2}\right) ; 8 \mathrm{~m} / \mathrm{s}$ & Area $\left(\mathrm{m}^{2}\right) ; 9 \mathrm{~m} / \mathrm{s}$ & Area $\left(\mathrm{m}^{2}\right) ; 10 \mathrm{~m} / \mathrm{s}$ \\
\hline 3 & 0.22 & 0.198 & 0.19 \\
4 & 0.24 & 0.21 & 0.195 \\
\hline
\end{tabular}

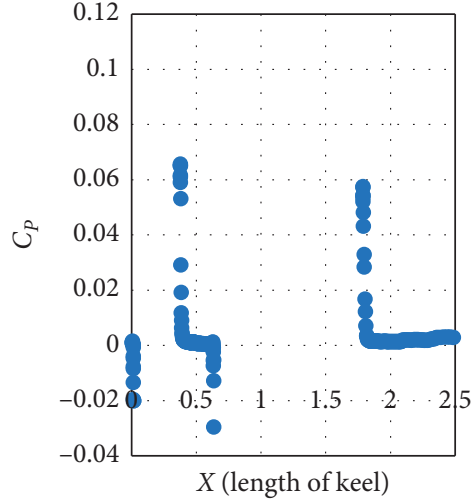

(a)

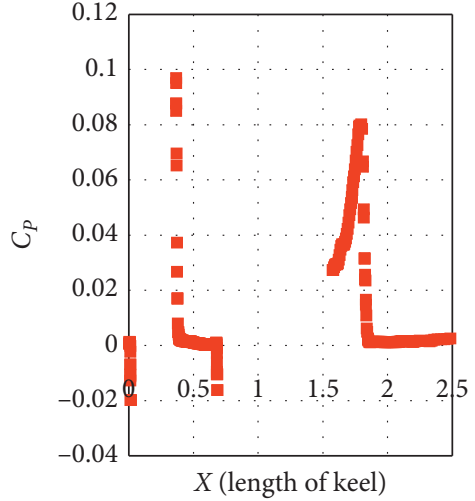

(b)

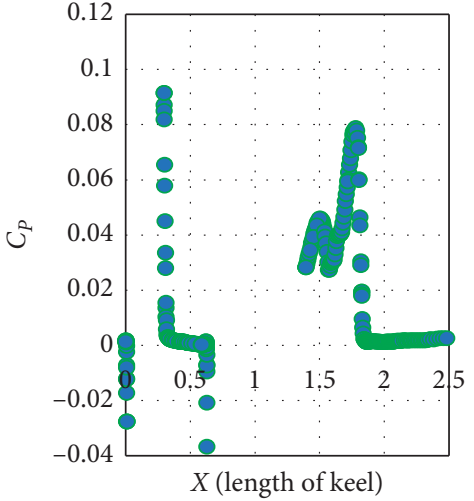

(c)

Figure 18: Pressure of keel line of case 3 at (a) $8 \mathrm{~m} / \mathrm{s}$, (b) $9 \mathrm{~m} / \mathrm{s}$, and (c) $10 \mathrm{~m} / \mathrm{s}$. 

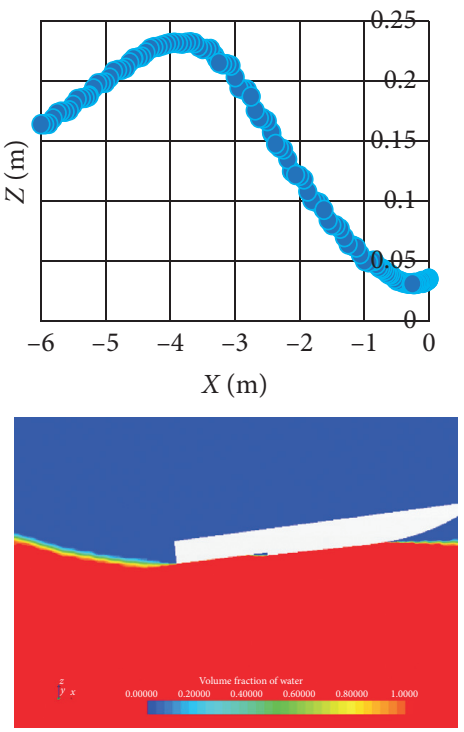

(a)
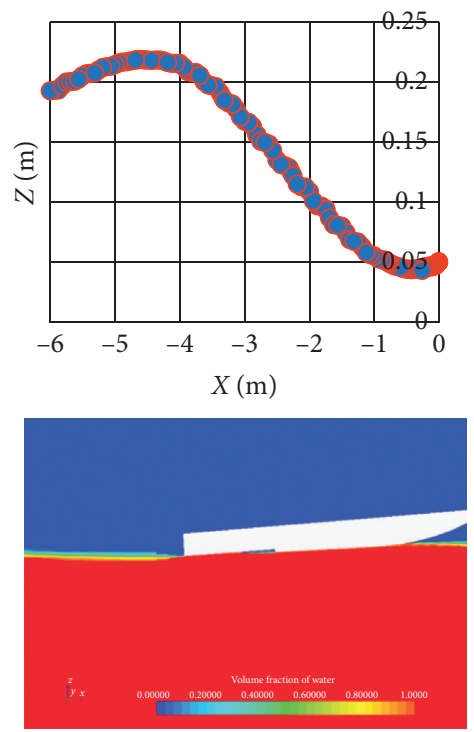

(b)
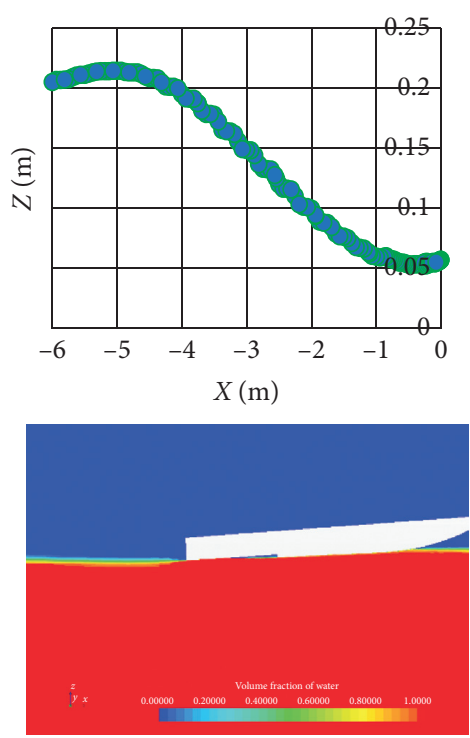

(c)

Figure 19: Trim and rooster tail of case 3 at (a) $8 \mathrm{~m} / \mathrm{s}$, (b) $9 \mathrm{~m} / \mathrm{s}$, and (c) $10 \mathrm{~m} / \mathrm{s}$.

By approaching pressure toward the transom and decreasing the trim, the longitudinal stability can be guaranteed. As evident in Figure 12, increasing the speed of the models leads to trim reduction. Figure 18 shows the pressure of keel line of case 3, which indicates that as the speed increases, the pressure in the aft of the vessel increases.

Figure 19 displays the trim reduction caused by an increase in speed and the wake profile behind case 3 at three speeds of 8,9 , and $10 \mathrm{~m} / \mathrm{s}$. Through an increase in speed, the wake profile enlarges. This enlargement is due to an increase in momentum of the mass of the water flowing beneath the vessel, which is caused by the increasing speed. The balance of the wetted surface area at the front of the first and second hulls enormously depends on the trim angle. The porpoising phenomenon is substantially caused by rapid oscillation of the trim angle. Another influential factor in the occurrence of porpoising is longitudinal distance between the step and transom. If this distance is too short, the bottom of the second hull might remain dry at high speeds, which leads to the loss of the aft pressure peak of the vessel and consequently leads to instability of the vessel.

One of the most critical points in studying stepped planing hulls is determination of their wetted surface area of the second hull. This task usually is done through the wetted keel and wetted chine of the second hull.

\section{Conclusion}

In the present paper, the occurrence of the porpoising phenomenon is studied for nonstep and single-step planing models at speeds higher than $8 \mathrm{~m} / \mathrm{s}$. Trim, resistance, and rise-up are obtained experimentally and numerically. The contours of the wetted surface area and pressure underneath the models are also presented. The studied models have a length of $2.64 \mathrm{~m}$ and a beam of $0.55 \mathrm{~m}$. These models are $1: 5$ scales of a prototype recreational vessel called Cougar. The center of gravity of all models is located at $0.791 \mathrm{~m}$ from the transom. The experimental study consists of single-step models with steps located at $670 \mathrm{~mm}$ from the transom. A single-step model is tested in the current paper, and its results are compared with the results of similar nonstep model, which have been previously investigated by Ghadimi et al. [39]. The nonstep model experiences porpoising at $8 \mathrm{~m} /$ $\mathrm{s}$ speed. However, the single-step models are stable up to $10 \mathrm{~m} / \mathrm{s}$ speed. Subsequently, using the Siemens PLM Star$\mathrm{CCM}+$ commercial code, the research is extended. After validating the numerical results against experimental measurements, ten other single-step cases with steps located at different distances ranging from 19 to 50 percent of the vessels' length at 8 to $10 \mathrm{~m} / \mathrm{s}$ speeds are simulated. Ultimately, the optimized location of the step is extracted with the aim of minimizing the resistance through DOE method (optimization by the design of experiment method). The results of this study can be summarized as follows:

(1) By increasing the longitudinal distance of the step from the transom, the models become more stable, but their resistance increases.

(2) Trim angles and rise-up increase, as the distance between step and transom decreases.

(3) Two of the simulated models are unstable at $10 \mathrm{~m} / \mathrm{s}$ speed, which is due to the increase in trim and reduction in the wetted surface area.

(4) Generally, the stable region of the vessel, which does not experience porpoising, has a direct relation with the trim of the vessel, and all cases can be categorized into three different sections of (a) unstable section, (b) stable section with optimized trim, and (c) stable section along with drag increase.

(5) According to the DOE method, the sensitivity of the drag to the step location is more than the speed and 
the optimum step place is situated at the location ratio of 24, which causes the lowest drag and makes the vessel stable.

\section{Nomenclature}

$\begin{array}{ll}B: & \text { Beam }(\mathrm{m}) \\ L: & \text { Length }(\mathrm{m}) \\ \text { LCG: } & \text { Longitudinal center of gravity } \\ m: & \text { Mass }(\mathrm{kg}) \\ \text { VCG: } & \text { Vertical center of gravity }(\mathrm{m}) \\ \beta: & \text { Deadrise angle (deg) } \\ \Delta: & \text { Weight }(\mathrm{N}) \\ \mathrm{Fr}_{B}: & \text { Beam Froude number } \\ \tau_{S}: & \text { Static trim angle (deg) } \\ Z: & \text { Rise-up } \\ R_{T}: & \text { Total resistance } \\ \mathrm{CG}: & \text { Center of gravity } \\ \mathrm{LOA}: & \text { Overall length of the vessel } \\ L_{\mathrm{s}}: & \text { Distance from the step to the transom stern } \\ P: & \text { Pressure distribution of the bottom of the vessel } \\ C_{\Delta}: & \text { Weight factor } \\ \lambda: & \text { Scale of models } \\ V: & \text { Underwater volume } \\ A_{P}: & \text { Wet floor area } \\ C_{\mathrm{AP}}: & \text { The length of the image of the wet boat floor } \\ \nabla: & \text { Underwater volume } \\ C_{L}: & \text { Lift factor } \\ \mathrm{N}: & \text { Newton. }\end{array}$

\section{Data Availability}

Data will be made available upon request.

\section{Conflicts of Interest}

The authors declare that they have no Conflicts of Interest

\section{Acknowledgments}

The authors express their sincere gratitude for the cooperation they received from the "National Persian Gulf Towing Tank" during the experiments.

\section{References}

[1] L. J. Doctors, Hydrodynamics of High-Speed Small Craft, The National Academies of Sciences, Engineering, and Medicine, Washington, DC, USA, 1985.

[2] D. Savitsky and M. Morabito, "Surface wave contours associated with the forebody wake of stepped planing hulls," Journal of Marine Technology, vol. 47, no. 1, pp. 1-16, 2010.

[3] D. L. Blount and E. P. Clement, "Resistance tests of a systematic series of planing hull forms," SNAME Transactions, vol. 71, pp. 491-579, 1963.

[4] D. Savitsky, "Hydrodynamic design of planing hulls," Journal of Marine Technology, vol. 1, no. 1, pp. 71-95, 1964.

[5] P. Ghadimi, A. Dashtimanesh, and Y. Faghfoor Maghrebi, "Initiating a mathematical model for prediction of 6-DOF motion of planing crafts in regular waves," International
Journal of Engineering Mathematics, vol. 2013, Article ID 853793, 15 pages, 2013.

[6] H. Haase, J. P. Soproni, and M. Abdel-Maksoud, "Numerical analysis of a planing boat in head waves using a $2 \mathrm{D}+\mathrm{T}$ method," Ship Technology Research, vol. 62, no. 3, pp. 131-139, 2015.

[7] P. Ghadimi, S. Tavakoli, A. Dashtimanesh, and R. Zamanian, "Steady performance prediction of a heeled planing boat in calm water using asymmetric $2 \mathrm{D}+\mathrm{T}$ model," Proceedings of the Institution of Mechanical Engineers, Part M: Journal of Engineering for the Maritime Environment, vol. 231, no. 1, pp. 234-257, 2017.

[8] M. G. Morabito, "Prediction of planing hull side forces in yaw using slender body oblique impact theory," Ocean Engineering, vol. 101, no. 1, pp. 47-57, 2015.

[9] P. Ghadimi, S. Tavakoli, and A. Dashtimanesh, "An analytical procedure for time domain simulation of roll motion of the warped planing hulls," Proceedings of the Institution of $\mathrm{Me}$ chanical Engineers, Part M: Journal of Engineering for the Maritime Environment, vol. 230, no. 4, pp. 600-615, 2016.

[10] E. Kahramanoglu, B. Yıldız, F. Çakııı, and H. Yilmaz, "Numerical roll damping prediction of a planing hull," Ships and Offshore Structures, pp. 1-10, 2020.

[11] M. H. Karimi, M. S. Seif, and M. Abbaspoor, "An experimental study of interceptor's effectiveness on hydrodynamic performance of high-speed planing crafts," Journal of Polish Maritime Research, vol. 2, no. 78, pp. 21-29, 2013.

[12] S. M. Sajedi, P. Ghadimi, M. Sheikholeslami, and M. A. Ghassemi, "Experimental and numerical analyses of wedge effects on the rooster tail and porpoising phenomenon of a high-speed planing craft in calm water," Journal of Mechanical Engineering Science, vol. 233, no. 13, pp. 46374652, 2019.

[13] S. Brizzolara and F. Serra, "Accuracy of CFD codes in the prediction of planing surfaces hydrodynamic characteristics," in Proceedings of the 2nd International Conference on Marine Research and Transportation, Naples, Italy, July 2007.

[14] J. Shuford, A Theoretical and Experimental Study of Planing Surfaces Including Effects of Cross Section and Plan Form, NACA-report-1355, National Advisory Committee for Aeronautics, Washington, DC, USA, 1958.

[15] D. Savitsky, M. F. DeLorme, and R. Datla, "Inclusion of whisker spray drag in performance prediction method for high-speed planing hulls," Journal of Marine Technology, vol. 44, no. 1, pp. 35-56, 2007.

[16] J. Seo, H.-K. Choi, U.-C. Jeong et al., "Model tests on resistance and seakeeping performance of wave-piercing highspeed vessel with spray rails," International Journal of Naval Architecture and Ocean Engineering, vol. 8, no. 5, pp. 442-455, 2016.

[17] Y. Jiang, H. Sun, J. Zou, A. Hu, and J. Yang, "Analysis of tunnel hydrodynamic characteristics for planing trimaran by model tests and numerical simulations," Ocean Engineering, vol. 113, pp. 101-110, 2016.

[18] A. De Marco, S. Mancini, S. Miranda, R. Scognamiglio, and L. Vitiello, "Experimental and numerical hydrodynamic analysis of a stepped planing hull," Applied Ocean Research, vol. 64, pp. 135-154, 2017.

[19] F. Cucinotta, E. Guglielmino, and F. Sfravara, "An experimental comparison between different artificial air cavity designs for a planing hull," Ocean Engineering, vol. 140, pp. 233-243, 2017.

[20] E. P. Clement and J. D. Pope, "Stepless and stepped planing hulls-graphs for performance prediction and design," 
International Shipbuilding Progress, vol. 8, no. 84, pp. 344360, 1961.

[21] E. P. Clement and J. O. Koelbel, "Optimized designs for stepped planing monohulls and catamarans," in Proceedings of the Conference on Intersociety High-Performance Marine Vehicles, pp. 24-27, Washington, DC, USA, June 1992.

[22] D. Svahn, "Performance prediction of hulls with transverse steps," A Report of Master's, The Royal Institute of Technology, KTH, Centre for Naval Architecture, Stockholm, Sweden, 2009.

[23] M. V. Makasyeyev, Numerical Modeling of Cavity Flow on Bottom of a Stepped Planing Hull, International Symposium on Cavitation, Ann Arbor, Michigan, 2009.

[24] D. J. Taunton, D. A. Hudson, and R. A. Shenoi, "Characteristics of a series of high-speed hard chine planing hulls-part 1: performance in calm water," International Journal of Small Craft Technology, vol. 152, pp. 55-75, 2010.

[25] D. J. Taunton, D. A. Hudson, and R. A. Shenoi, "Characteristics of a series of high speed hard chine planing hulls-part II: performance in waves," International Journal of Small Craft Technology, vol. 153, pp. 1-22, 2011.

[26] E. Lee, M. Pavkov, M. Pavkov, and L. McCue-Weil, "The systematic variation of step configuration and displacement for a double-step planing craft," Journal of Ship Production and Design, vol. 30, no. 2, pp. 89-97, 2014.

[27] C. R. Timmins, "Yaw stability of a recreational stepped planing hull," Journal of Soc Naval Architect Marine, Engineering, vol. 119, pp. 448-458, 2014.

[28] M. M. Doustdar and H. Kazemi, "Effects of fixed and dynamic mesh methods on simulation of stepped planing craft," Journal of Ocean Engineering and Science, vol. 4, no. 1, pp. 33-48, 2019.

[29] A. Najafi and H. Nowruzi, "On hydrodynamic analysis of stepped planing crafts," Journal of Ocean Engineering and Science, vol. 4, no. 3, pp. 238-251, 2019.

[30] F. Di Caterino, R. Niazmand Bilandi, S. Mancini, A. Dashtimanesh, and M. De Carlini, "A numerical way for a stepped planing hull design and optimization," Journal of Technology and Science for the Ships of the Future, pp. 220229, 2018.

[31] P. Ghadimi and S. Panahi, "Numerical investigation of hydrodynamic forces acting on the non-stepped and doublestepped planing hulls during yawed steady motion," Proceedings of the Institution of Mechanical Engineers, Part M: Journal of Engineering for the Maritime Environment, vol. 233, no. 2, pp. 428-442, 2019.

[32] A. Afriantoni, R. Romadhoni, and B. Santoso, "Study on the stability of high speed craft with step hull angle variations," in Proceedings of the The 8th International and National Seminar on Fisheries and Marine Science, Riau, Indonesia, January 2020.

[33] Y. Dongmei, S. Zhiyuan, Y. Jiang, and Z. Gao, "A study on the air cavity under a stepped planing hull," Journal of Marine Science and Engineering, vol. 7, no. 12, pp. 465-483, 2019.

[34] J. Zou, S. Lu, Y. Jiang, H. Sun, and Z. Li, "Experimental and numerical research on the influence of stern flap mounting angle on double-stepped planing hull hydrodynamic performance," Journal of Marine Science and Engineering, vol. 94, pp. 103-110, 2019.

[35] P. Ghadimi, S. Panahi, and S. Tavakoli, "Hydrodynamic study of a double-stepped planing craft through numerical simulations," Journal of the Brazilian Society of Mechanical Sciences and Engineering, vol. 41, no. 2, 2019.
[36] H. Kazemi, M. Salari, H. Nowruzi, and A. Najafi, "Hydrodynamics analysis of stepped planing hull under different physical and geometrical conditions," Journal of the Brazilian Society of Mechanical Sciences and Engineering, vol. 41, no. 9, pp. 360-372, 2019.

[37] R. T. Chooran, R. Shafaghat, and R. Yoosefi, "Numerical investigation of step depth effects on hydrodynamic performance of planing hull using dynamic mesh and two degree of freedom model," Journal of Mechanical Engineering, vol. 3, no. 2, pp. 139-148, 2019.

[38] A. Najafi, H. Nowruzi, M. Salari, and H. Kazemi, "The hydrodynamic resistance of stepped planing hulls under different geometrical and physical conditions," Journal of the Maritime University of Szczecin, vol. 58, no. 130, pp. 24-31, 2019.

[39] J. P. Day and R. J. Haag, Planing Boat Porpoising. Thesis, Webb Institute of Naval Architecture, Glen Cove, NY, USA, 1952.

[40] T. Celano, "The prediction of purposing inception for modern planing craft," SNAME Trans, vol. 106, pp. 269-292, 1998.

[41] D. Blount and L. Codega, "Dynamic stability of planing boats," Marine Technology, vol. 29, no. 1, pp. 4-12, 1992.

[42] P. Ghadimi, S. M. Sajedi, and P. Taghikhani, "Statistical analysis of wedge effect on the seakeeping of a planing hull in irregular waves at the onset of the planing region," Journal of Applied Fluid Mechanics, vol. 11, no. 4, pp. 905-918, 2018.

[43] ITTC, "Testing and extrapolation methods high speed marine vehicles," in Proceedings of the Specialist Committee on Powering Performance Prediction 25th ITTC, Nantes, France, July 2008.

[44] ITTC, Uncertainty Analysis in CFD Verification a Validation 7, ITTC, Nantes, France, 2008.

[45] CD-Adapco, STAR CCM + User's Guide, Version 9.06, 2014.

[46] S. Mancini, The Problem of the Verification and Validation Processes of CFD Simulations of Planing Hulls, PhD Thesis, Department of Industrial Engineering University of Naples "Federico II", Naples, Campania, Italy, 2016.

[47] ITTC, Proceedings of Twenty-Sixth International Towing Tank Conference, ITTC, Nantes, France, 2011.

[48] I. B. Celik, U. Ghia, P. J. Roache, C. J. Freitas, H. Coleman, and P. E. Raad, "Procedure for estimation and reporting of uncertainty due to discretization in CFD applications," Journal of Fluids Engineering, vol. 130, no. 7, pp. 1-4, 2008. 